\title{
The Capital Gains from Trade are not Enough: Evidence from the Environmental Accounts of Venezuela and Mexico*
}

\author{
M.del Mar Rubio \\ Universitat Pompeu Fabra \\ Department of Economics and Business
}

\begin{abstract}
In principle, a country can not endure negative genuine savings for long periods of time without experiencing declining consumption. Nevertheless, theoreticians envisage two alternatives to explain how an exporter of non-renewable natural resources could experience permanent negative genuine savings and still ensure sustainability. The first one alleges that the capital gains arising from the expected improvement in the terms of trade would suffice to compensate for the negative savings of the resource exporter. The second alternative points at technological change as a way to avoid economic collapse. This paper uses the data of Venezuela and Mexico to empirically test the first of these two hypotheses. The results presented here prove that the terms of trade do not suffice to compensate the depletion of oil reserves in these two open economies.
\end{abstract}

Keywords: exhaustible resources, environmental accounts, net national product, genuine savings, foreign trade.

JEL: Q01, N5, P24, F18

\footnotetext{
* The London School of Economics and Political Science, the Economic and Social Research Council, the Economic History Society, the Institute of Historical Research, all in the United Kingdom, and the Fulbright Commission in Spain, provided financial support at different stages of this research. I am grateful to the staff of the library of the Oxford Institute for Energy Studies, Biblioteca del Banco de Mexico and Biblioteca Central de Petróleos Mexicanos for their assistance. Thanks to all those at LSE (and elsewhere) who have commented on my work while in progress. I am particularly grateful to N.Crafts, M.Weale and R. Thorp, whose comments contributed importantly to this research. Part of the research was completed while being visiting scholar at the University of California, Berkeley, thanks to the facilities of the Institute of Business and Economic Research and the Economics Department. The usual disclaimers apply. Comments are welcomed to mar.rubio@upf.edu
} 


\section{The Capital Gains from Trade are not Enough: Evidence From the Environmental Accounts of Venezuela and Mexico}

The traditional measure of a nation's rate of accumulation of wealth is gross saving. This is calculated as a residual: GNP minus public and private consumption. Gross saving represents the total amount of produced output that is set aside for the future. Gross savings rates can say little about the sustainability of development, however, because productive assets depreciate through time: if this depreciation is greater than gross saving, then aggregate wealth is in decline. Net saving, total gross saving less the value of depreciation of produced assets, is one step closer to a sustainability indicator, but focuses narrowly on produced assets. Environmental economist assimilate natural resources to man made capital, since a country's consumption may be mainly supported by draining natural resources, i.e. from the depreciation of natural capital. Traditionally computed net savings ignore the depreciation of natural capital. Once natural capital depreciation is also subtracted we arrive to the concept of 'genuine savings'.

Hartwick [20] and Solow [55], building on the concepts of Hicks [23] established that in order to achieve constant real consumption through time (the lower bound of sustainability) it is necessary to keep the underlying capital stock constant. It becomes a requirement that the value of the net change in the total capital stock (that is the genuine savings) must be equal or greater than zero. In principle, a country can not therefore endure negative genuine savings for long periods of time without experiencing declining consumption, or the total collapse of its economy.

Nevertheless, theoreticians have envisaged some possibilities that would allow an exporter of non-renewable natural resources to experience persistent negative genuine savings and still ensure sustainability. The first one alleges that the capital gains arising from the expected improvement in the terms of trade would allow the resource exporter to compensate for the negative savings. The second alternative points at technological change as a way to avoid economic collapse. The gains from trade have now been included in environmental accounting models. Some of the more representative are those of Asheim [1, 2], Hartwick [22], Newmayer [42], Sefton and Weale [54] and Weale [64], while the technical change avenue remains largely unexplored exception made of the contributions of Weitzman [66].

The exercises in this paper use the historical data of Venezuela and Mexico to test ex post the validity of the predictions of the models that include capital gains from trade in modifying the genuine savings indicator. Mexico and Venezuela have been oil producers since the dawn of the oil era. Mexico started commercial production in 
1901 and was the world's greatest oil exporter and second producer by 1921 . Venezuela replaced Mexico in this position during the inter-war years. While Mexico nationalized its oil industry by 1938 and followed an inward-looking strategy of depleting the oil just to the extent necessary to fulfil domestic requirements, Venezuela adopted a pure export-oriented strategy, leaving her oil in foreign hands until 1976. After almost forty years of looking at each other with a mixture of criticism and wonder, defending their own exploitation strategy as the best possible, Mexico and Venezuela ended the twentieth century as state-owned medium-sized oil exporters. The real benefit of ex post analysis is in making the most of the opportunity to improve the analytical model used as much as in understanding the path that history took.

The order of exposition in the paper is as follows:

1. The first exercise introduces the concept and computes the value of genuine savings indicator for the Venezuelan and Mexican economies. By emphasising the level of genuine savings, we are in effect asking the question: how much of the net (environmentally adjusted) income was actually consumed? Or in other words, were the countries living beyond their means? In this first exercise Venezuela appears to have been living beyond its means for a very long period of time, yet the expected decline in well-being cannot be observed. Hence, the prediction of unsustainability implied by negative genuine savings comes into question.

2. The second exercise examines the role of the terms of trade in modifying the standard sustainability indicator in two alternative ways:

a) Using the methodology of Sefton and Weale [54] (imputed income method) that takes into account the expected capital gains from trade for the adjustment of net income. This second indicator reverses the view of the previous exercise, showing that Venezuela and Mexico were never consuming beyond their means if the expected gains from the terms of trade are taken into account.

b) Using one of the methodologies proposed in the national income literature for assessing the effect of the actual changes in the terms of trade on national income. The additions to welfare income due to the historical changes in the terms of trade differ substantially from the expected terms of trade effects derived from Sefton and Weale model resulting in the return of the paradox of negative genuine savings without observable declines in well-being.

The exercises of this paper are restricted by the availability of traditional macroeconomic data. In particular, the short series on national income (NNP) shorten the 
period of analysis to 1936-1985 for Venezuela and to 1950-1989 for Mexico. This does not affect the main thrust of the argument.

The results of this paper are on line with the findings of Vincent et al. [63], who estimated that Indonesia would have to invest more in order to sustain its consumption levels when using an open economy model than using a closed economy model. These results question the view that the exporter of natural resources 'does not have to do any investing in order to maintain its level of income constant, so the whole of the revenue is available for consumption' given the expected gains in the terms of trade (Weale [64], pp.99-100). In the absence of technical change, consuming the whole of the revenue may be a good theoretical option but a bad economic decision.

\section{The Standard Sustainability Indicator: Genuine Savings}

The genuine savings indicator can be expressed in the form

$$
Z=\frac{S}{Y}-\frac{\delta_{M} K_{M}}{Y}-\frac{\delta_{N} K_{N}}{Y}
$$

where $S$ is gross savings, $\delta_{M} K_{M}$ and $\delta_{N} K_{N}$ are man-made capital and natural capital depreciation respectively and $Y$ is total output in the economy. According to its authors, Pearce et al. [45], [46], $Z$ 'is an intuitive zero-order rule for determining whether a country is on or off a sustainable development path at any one point in time. The value of $Z$ must be either zero or positive to ensure sustainability.'

By emphasising the level of genuine savings, we are in effect asking the question: how much of the adjusted income was actually consumed? Gross savings are GNP minus consumption. Net savings are gross savings minus depreciation of physical capital, which can also be expressed as (GNP - $\left.\delta_{M} K_{M}\right)-C=N N P-C$. Subtracting natural capital depreciation from these net savings we arrive to genuine savings, $N N P-\delta_{N} K_{N}-C=N N P_{a d j} C$. Thus the $Z$ indicator can actually be re-expressed in the following terms:

$$
Z=\frac{N N P_{a d j}-C}{Y}
$$

where $N N P_{\text {adj }}$ is the environmentally adjusted net income (that is, $N N P-\delta_{N} K_{N}$ ) and $C$ is the sum of public and private consumption. Observe that, in the way it was originally formulated, the genuine savings indicator implies the use of the net price method of Repetto et al. [51] for adjusting the traditional NNP. This method establishes that natural capital depreciation, $\delta_{N} K_{N}$, matches the total resource rent $\left(N_{t}\right)$ for the year, where the usual measure for the resource rent has been the surplus revenue accruing 
to the owners of the resource after accounting for the contribution of capital and labour inputs.

Figures 1 and 2 compare the sizes of the man-made capital depreciation $\left(\delta_{M} K_{M}\right)$ as recorded in the traditional accounts, with the measure of natural capital depreciation $\left(\delta_{N} K_{N}\right)$, that is $N_{t}$, estimated by Rubio [52] for the depletion of oil resources in Mexico and Venezuela.

Natural resource depreciation -approximated by the depreciation of oil resources- is larger than physical capital depreciation throughout the period studied in the case of Venezuela. For Mexico the scale of the natural depreciation cannot be dismissed from the 1970s onwards. Prior to that date the level of natural capital depreciation for Mexico was of the order of 1.5 percent of traditional GDP. At least two caveats are required in relation to this comparison. First, it is worth bearing in mind that the natural capital depreciation estimates calculated here are only considering a single natural resource, i.e. oil. It is the resource that generated the greatest rents and therefore the greatest depreciation during the century, but the depreciation of other natural resources should ideally be also accounted for (consider, for instance, natural gas). Therefore, the figures shown here underestimate natural depreciation. In the second place, the comparison should be regarded with caution since the historical estimates of consumption of fixed capital are feeble, especially in the case of Mexico. All in all, however the message from Figures 1 and 2 is clear: natural depreciation is by no means negligible. 
Figure 1: Man-made capital VS natural capital depreciation.

Venezuela 1920s-1980s (mill. Bolivars current prices)

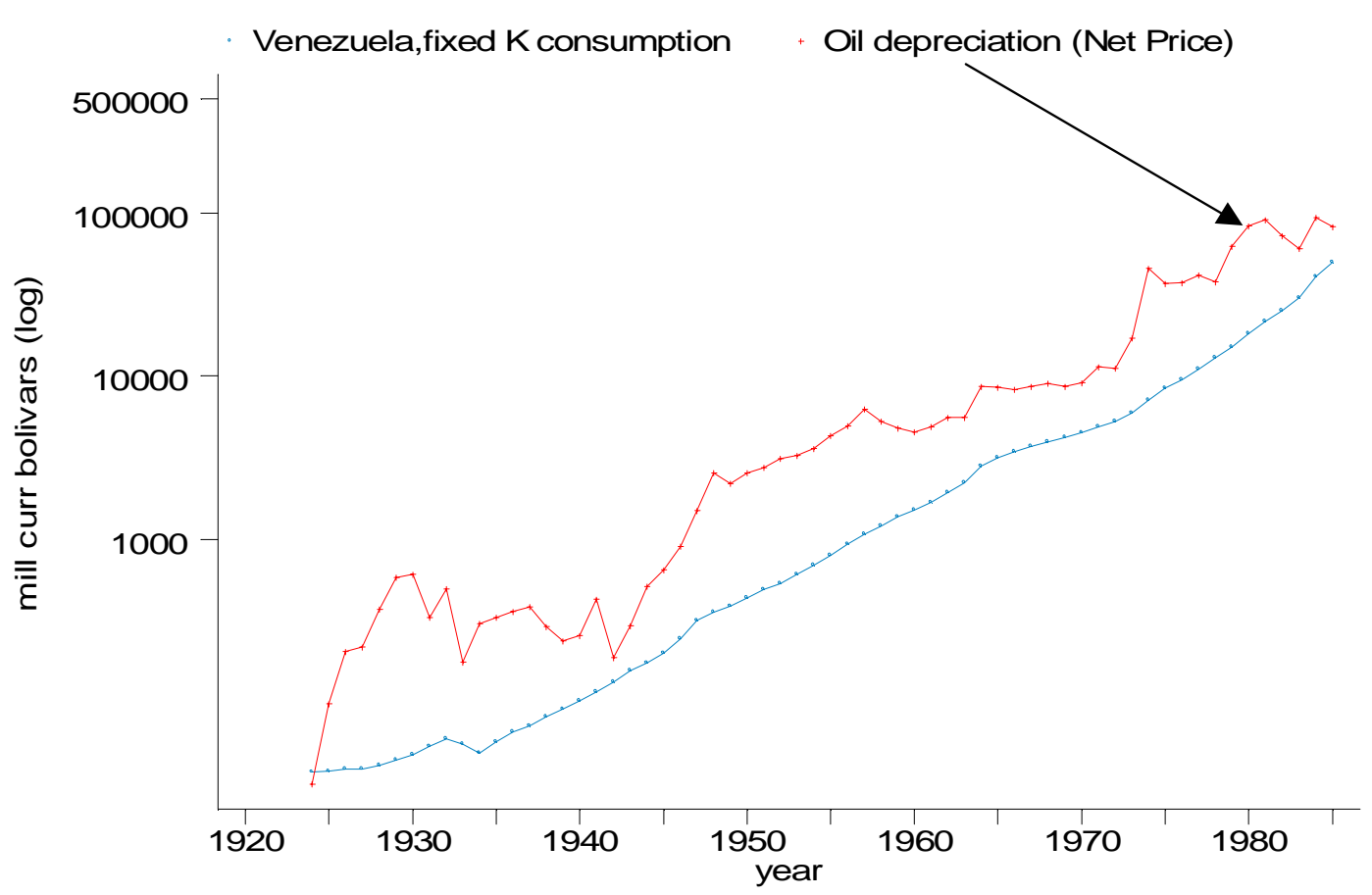

Notes and sources: Fixed capital consumption $\left(\delta_{M} K_{M}\right)$ data sources in Appendix $D$ and natural capital depreciation $\delta_{N} K_{N}$ from Rubio [52] as listed in Table A.1 in Appendix 1

Figure 2: Man-made capital VS natural capital depreciation. Mexico1920s-1980s (mill. Pesos current prices (log))

Mexico, fixed K consumption - Oil depreciation (Net Price)

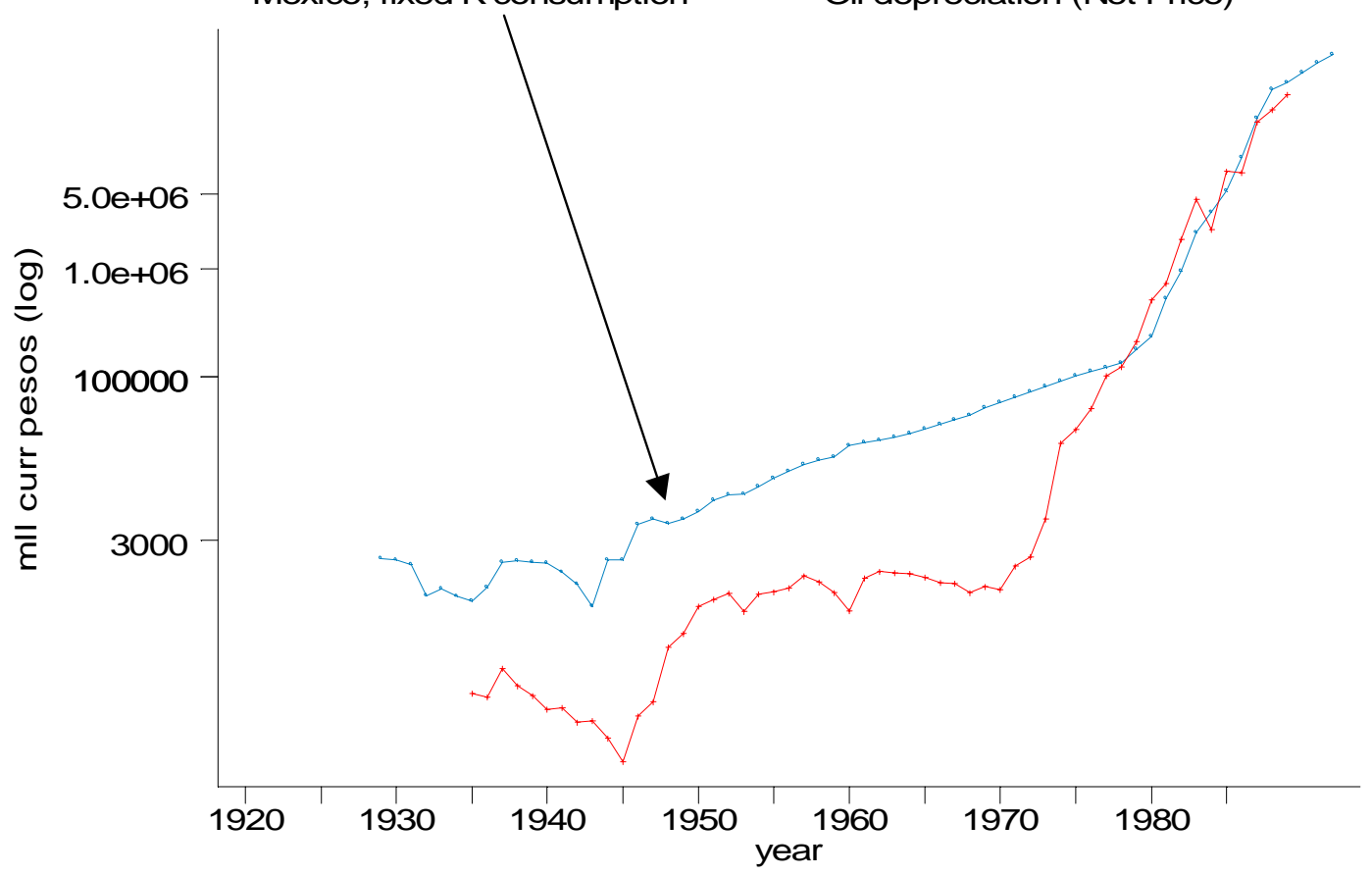

Notes and sources: Fixed capital consumption $\left(\delta_{M} K_{M}\right)$ data sources in Appendix D and natural capital depreciation $\delta_{N} K_{N}$ from Rubio [52] and listed in Table A.2 in Appendix 1 
These estimates of natural depreciation are used for the computation of the $Z$ indicator described in equation [1]. Figures 3 and 4 offer the graphical representation of the gross, net and genuine savings as percentage of GDP for Mexico and Venezuela.

Figure 3: Genuine savings. Venezuela 1936-1985 (percentage over GDP)

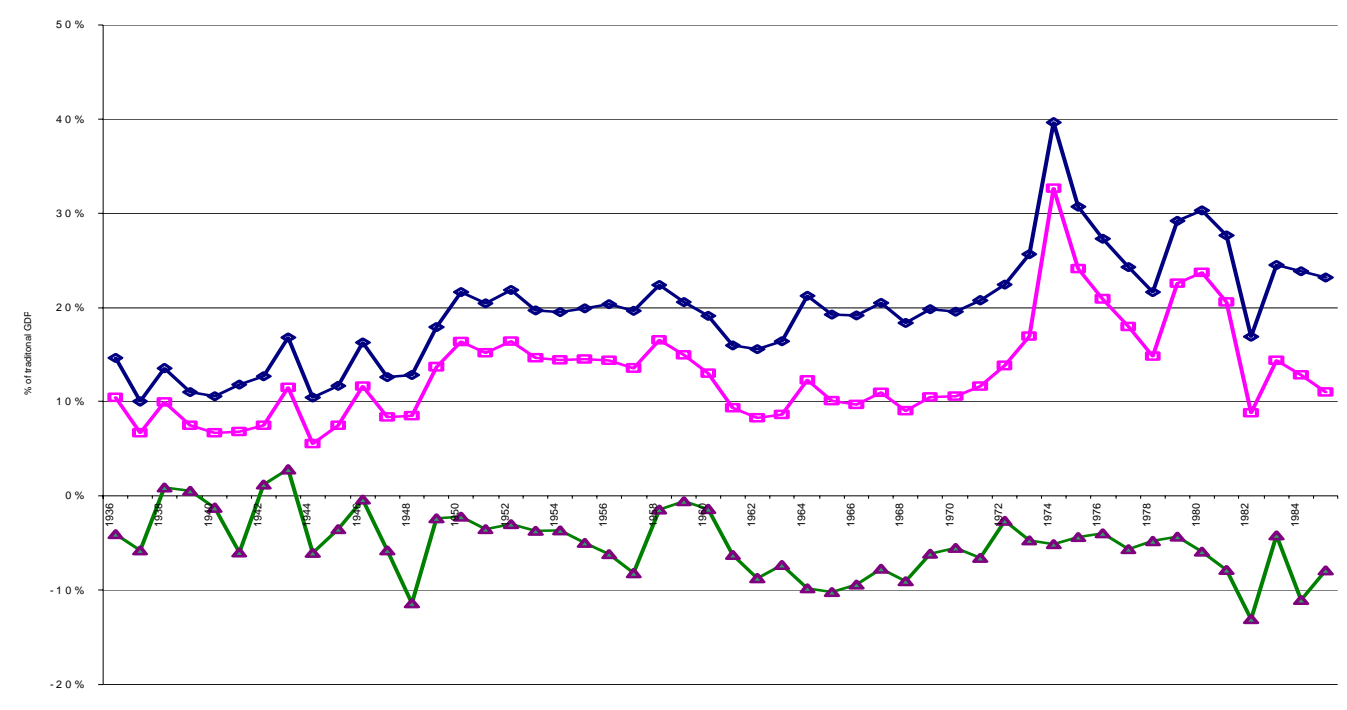

Source: Table 3

Figure 4: Genuine savings. Mexico 1950-1985 (percentage over GDP)

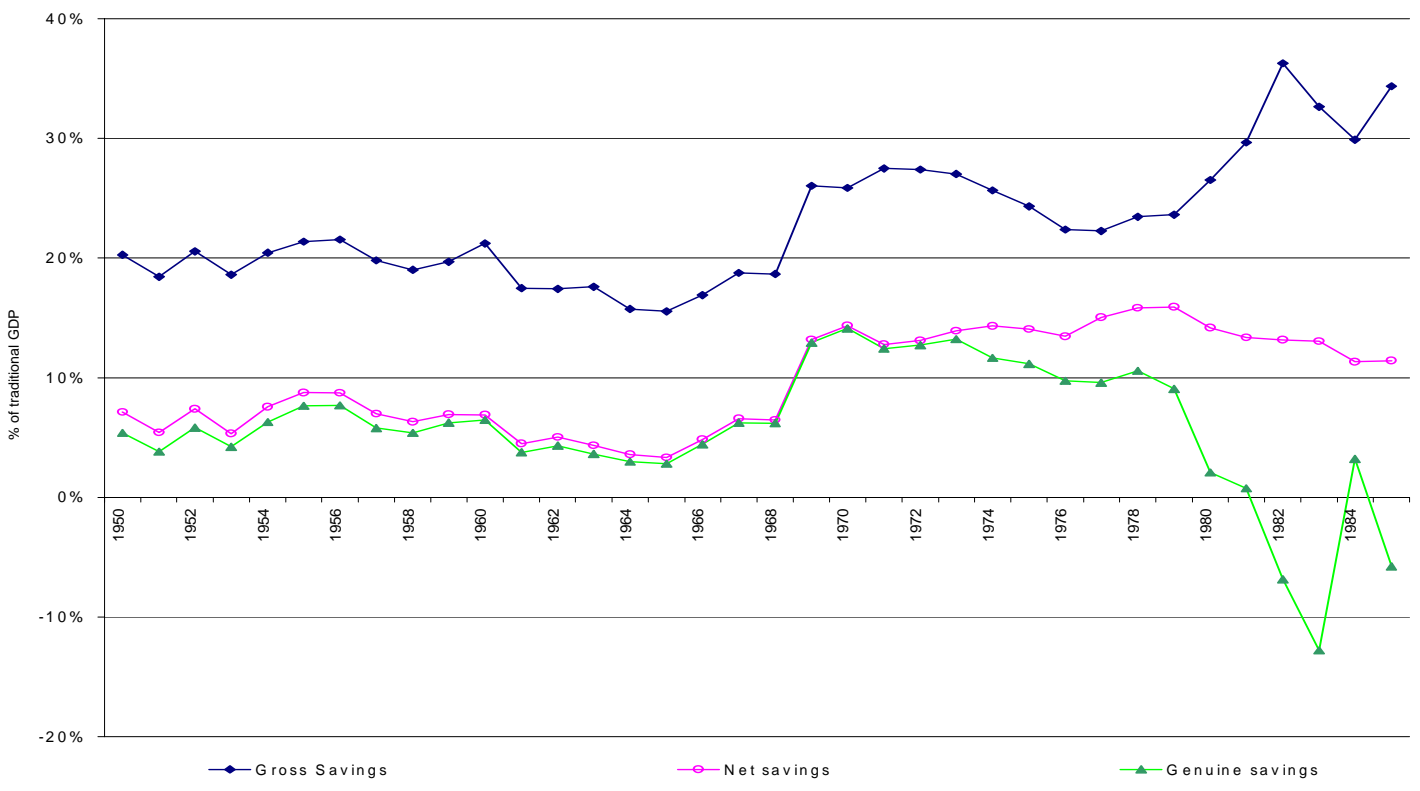

Source: Table 4. 
This first exercise shows Venezuela's $Z$ indicator taking negative values by the 1930 s and from 1944 it permanently failed to satisfy the rule in equation [1]. This is a striking result for an economy historically portrayed as an exceptionally high saver. In 1961 the IBRD reported 'Venezuela has devoted 30 percent of its GNP to gross investment, a proportion equalled or exceeded in only a few European countries notably west Germany and Norway' [26]. The Mexican indicator only turned negative only for a couple of years in the early 1980s. These results are on the line of those reported by Pearce and Atkinson [46](p.173) for Mexico for the year 1985 (0 genuine savings). The results presented here also coincide with the World Bank [67] (p.12) for the period 1970-1993, which reports that 'strong savers like Brazil and Chile are offset by the genuine dissaving of Venezuela and Ecuador and the near-zero genuine savings of Mexico'. In theory, these results indicate that Venezuela has been living beyond its means to a greater extent and for a longer period than Mexico.

According to the World Bank [67] (p.8) 'persistently negative rates of genuine savings must lead, eventually, to declining well-being'. The puzzling question regarding this prediction is: for how long can a country endure negative genuine savings before the eventual decline of well-being becomes apparent? If Mexican results were the measure, it could be argued that a couple of years with negative genuine savings are sufficient to observe a decline in well-being by the mid 1980s. In contrast, in Venezuela negative rates of genuine savings occurred continuously for over 40 years and yet, declining well-being was only perceived from the 1980s, and according to some authors, only from the 1990s onwards (see Coronil [12] and Goodman [15]). Not in vain Venezuela has the best overall performance in Latin America throughout the twentieth century in terms of traditional GDP growth according to Hofman [24] (p.87). By any standards the negative rents of Venezuela were persistent enough, yet the expected decline in well-being was greatly delayed. Hence, the predicted unsustainability of negative genuine savings comes into question.

As mentioned above, several authors have theorised about the role of capital gains arising from (1) improved terms of trade and (2) technological change in modifying the $Z>0$ rule. The next section tests empirically the first of these theoretical objections to the genuine savings indicator.

\section{The Effects of the Terms of Trade}

The national income literature has long noted the problem that traditional indicators in 'may not be a good indicator of national welfare in an open economy experiencing substantial change in its terms of trade.' Hamada et al. [19] (p.752). This occurs because traditional measures of output and income fail to account for the impact of 
changing terms of trade on the consumption possibilities of the economy. Gutman [17] summarised the many attempts to adjust for the terms of trade impact on the measurement of national income, although it does not includes the later attempt by Hamada et al. [19]. The general result from those attempts is in words of Irwin [27] (p.100) 'when the terms of trade deteriorated, measures of economic growth tended to overstate gains in real income; when they improved, those measures understated such gains.'

This observation has not escaped the analysis of environmental accountants. Sefton and Weale [54] argued that the net price method is inappropriate for adjusting the net income for the depletion of oil reserves in open economies precisely because it ignores the effects on welfare income of the expected improvement of the terms of trade of an oil exporter (the model explicitly mentioned by Sefton and Weale is not the net price of Repetto, but Dasgupta et al. [13] and Hartwick [21], which are the foundations of Repetto's model). Accordingly, the sustainability rule Z presented in the section above would differ for open and closed economies. Sefton and Weale derived the necessary adjustment for an open economy that exports natural resources. Their suggestion is that the adjusted income would be incomplete without an imputed income for the stock of the resource targeted for export. This imputed income should be included in the measures of adjusted income in order to take into account the effects from the expected gains in the terms of trade. In fact their model suggest two adjustments: an imputed income for the stock of resource targeted for export and a rate of interest effect. Yet, the second adjustment is considered 'harder to estimate and it seems reasonable to assume is negligible as real interest rates can be expected to remain almost constant in the long run' (Sefton and Weale [54] p.46). Appendix 2 offers a brief discussion of Sefton and Weale method. The environmentally adjusted income corresponding to Sefton and Weale methodology responds to the following formulation:

$$
N N P_{a d j}=N N P-N_{t}+\frac{i}{1+i} V t
$$

where NNP is the traditionally computed net income, $N_{t}$ is still the resource rent (the net price in other words) and the last term corresponds to the expected gains from the improved terms of trade. In this second exercise, the $Z$ indicator is re-estimated using equation [2], but rather than adjusting the traditional income by the net price method, the net income is adjusted by the imputed income method just defined. 
Figure 5:Genuine Savings Taking into Account the Expected Gains from Trade. Venezuela 1936-1985 (percentage over traditional GDP)

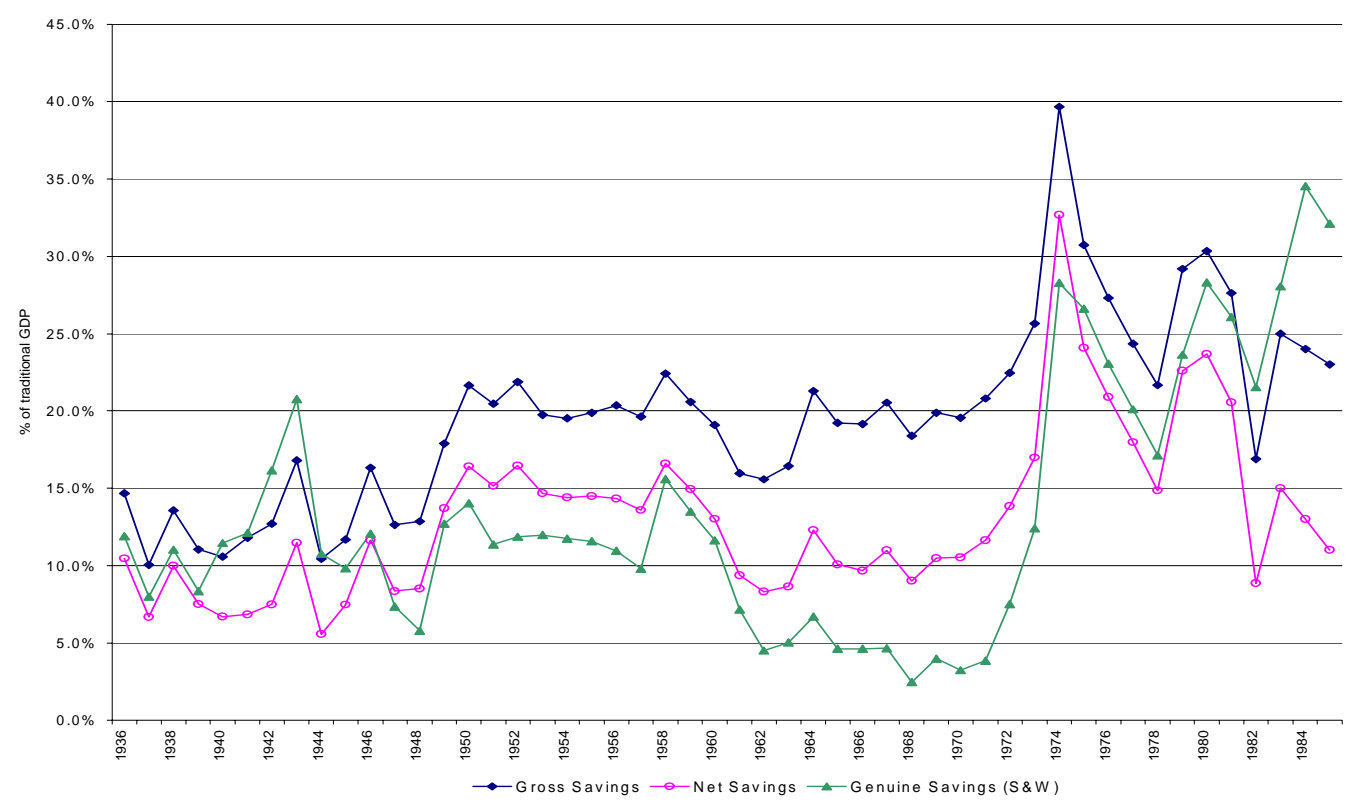

Sources: Gross and net savings as in Table 3. Genuine savings correspond to the NNP minus the imputed income adjustment in Table A.3 in Appendix 1 (a discount rate of $6 \%$ is used here).

Figure 6:Genuine Savings Taking into Account the Expected Gains from Trade. Mexico 1950-1985 (percentage over traditional GDP)

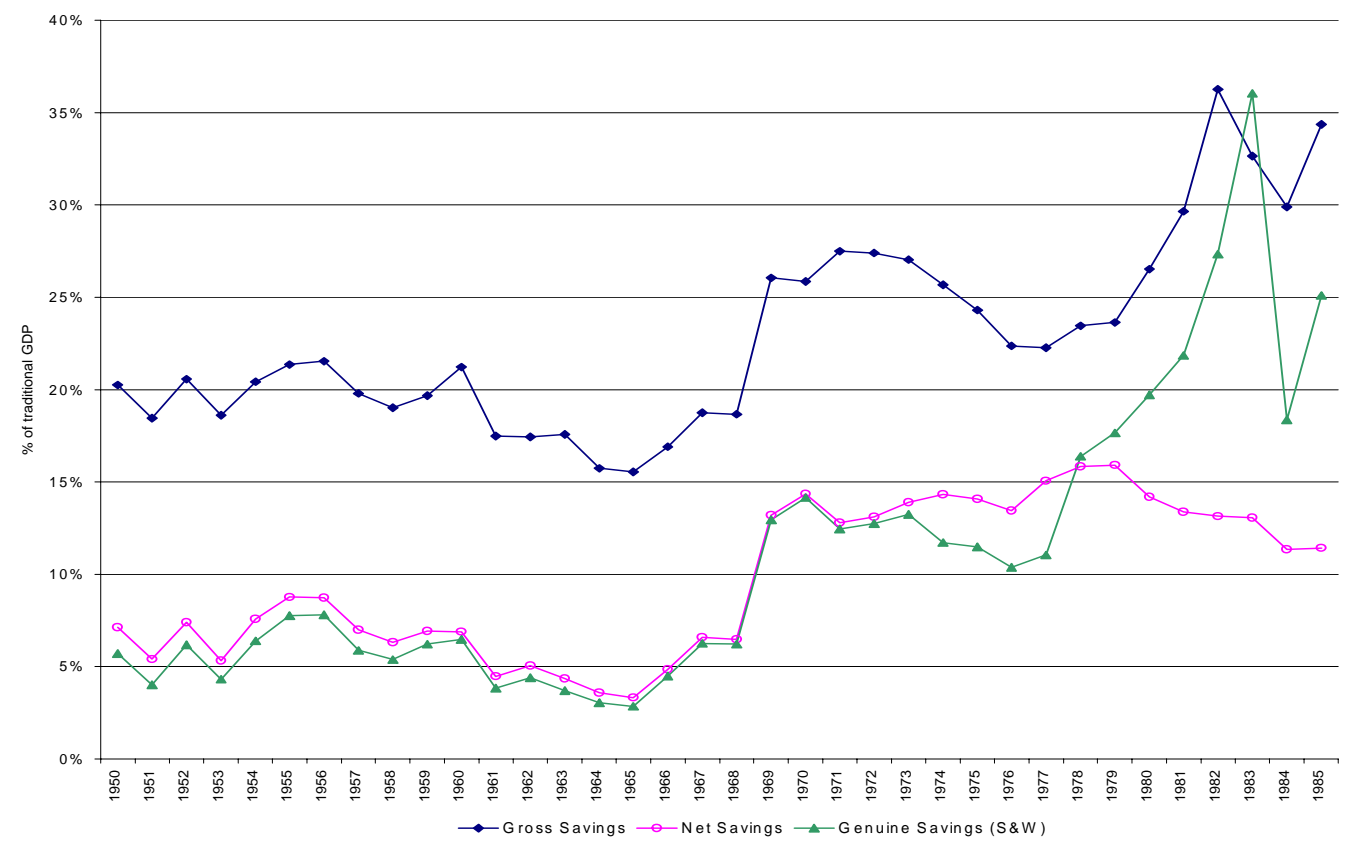

Sources: Gross and net savings as in Table 4. Genuine savings correspond to the NNP minus the imputed income adjustment in Table A.4 in Appendix 1 (a discount rate of $6 \%$ is used here). 
Figures 5 and 6 illustrate the effects of the expected gains from trade in modifying the $Z$ indicator. When net income is adjusted using the imputed income method, it appears that Venezuela and Mexico consumed within their means throughout the period analysed. According to the results the levels of consumption were not necessarily unsustainable given the expected continuous improvement on the terms of trade of a resource exporter. However, some important caveats should be taken into account.

The expected gains from trade in Sefton and Weale method arise from the application of Hotelling's rule. That is the expectation that the resource rent is going to grow at the rate of interest in the economy until the resource is exhausted. But the analysis of the behaviour of the rents calculated for Mexico and Venezuela in the section above revealed that there is no historical evidence supporting Hotelling's principle (rents have not grown at the rate of interest). Consequently, the possibility of escaping from negative savings in open economies through the improvement of the terms of trade is considerably reduced and needs further investigation.

The obvious way to establish the role of the terms of trade is to observe their historical evolution. Figures 7 and 8 reveal the terms of trade for Venezuela and Mexico for the relevant periods. Contrary to what would be expected from the application of Hotelling's rule, the terms of trade do not improve continuously in either of the two countries. Venezuelan terms of trade improved markedly from 1942 to 1957 and during the 1970s, but from the end of the 1958 until 1972 remained constant and from the early 1980s declined notably. In the case of Mexico, before it re-started its oil exports, the terms of trade exhibit a modest upward trend; when oil regained a significant position in Mexican exports from 1974, the terms of trade improved briefly but started to decline from the 1980s and finally arrived at a constant level. The historical terms of trade do not satisfy the theoretical predications of the imputed income method. 
Figure 7: Venezuelan Terms of Trade, 1928-1989 (1968=100)

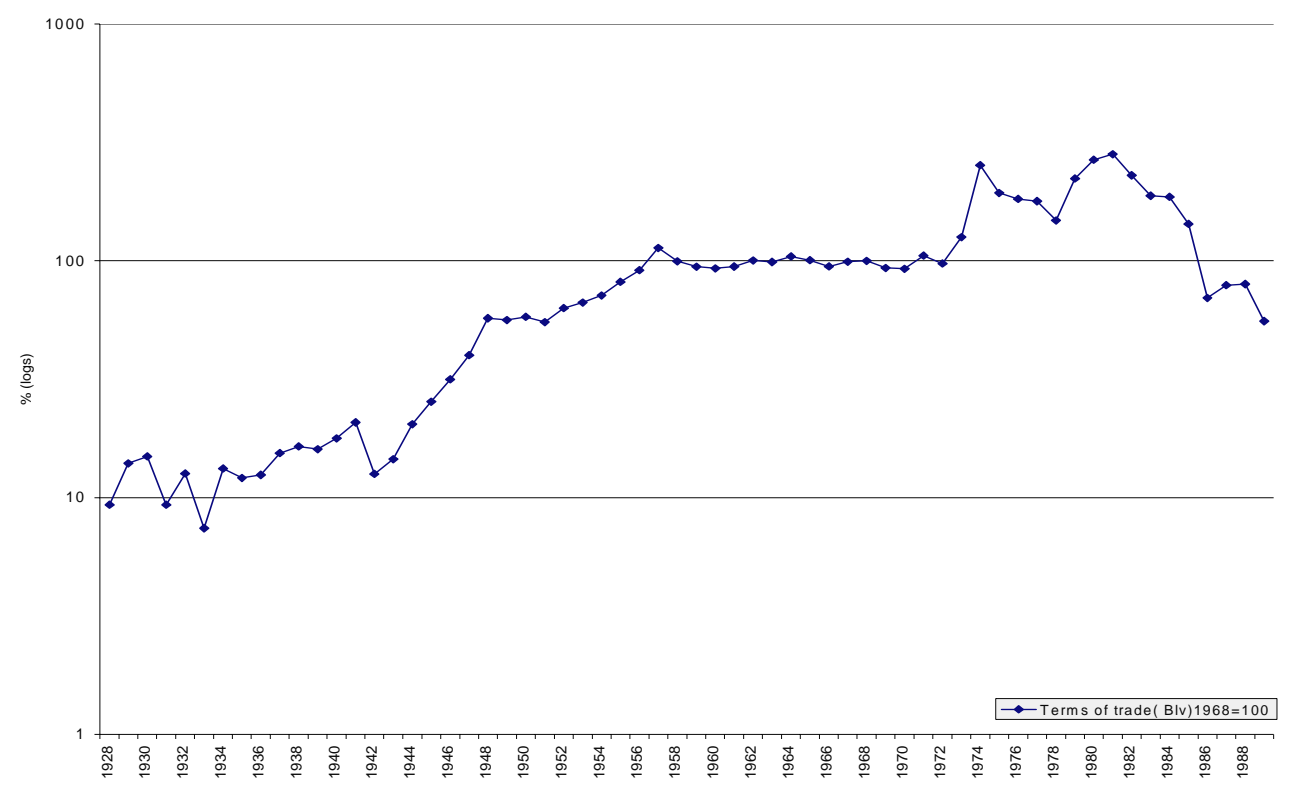

Sources: Terms of trade calculated as the ratio between exports and imports price indexes. Export price index was elaborated using the exports and prices series of oil from Appendixes A and B. It is worth recalling that oil exports represent the vast majority of Venezuelan exports for the dates shown. Imports price index from Baptista [9].

Figure 8: Mexican Terms of Trade, 1960-1989 (1995=100)

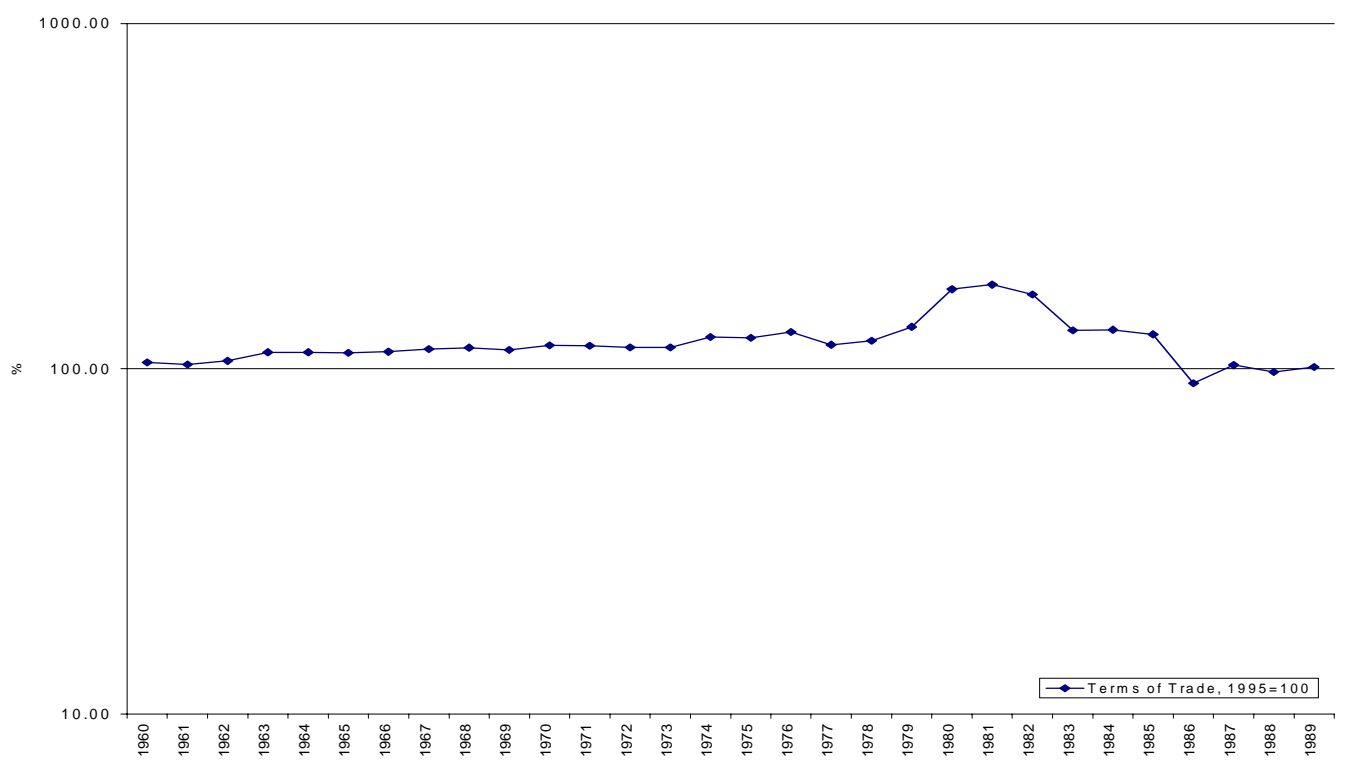

Source : Easterly et al. [14] 
It is possible to argue that even if the rents had increased at the rates assumed by Hotelling's rule, the gains from the terms from trade may have not continuously increased. Some of the gains apparently associated with the improved terms from trade may be lost since oil is a basic input for producing the goods that the oilexporter-country needs to import. This is actually a common assumption in models that take natural resources into account (for instance Sefton and Weale [54]). Higher oil prices will influence the price of imports and the gains from the terms of trade will be reduced. The theoretical models do not consider this feedback effect.

These results do not overrule the fact that the terms of trade have an effect in modifying the $Z$ indicator. Although Mexico and Venezuela did not experience the continuous improvement in the terms of trade implicitly assumed by the imputed income method, both countries were at different points in time open economies experiencing substantial changes in their terms of trade. As a consequence, their welfare incomes (their consumption possibilities) will differ from the standard income measures and this will have an effect on whether they were living beyond their means.

A re-estimation of the $Z$ indicator is needed taking into account the effect on income of the actual changes in the terms of trade instead of the expected gains from the terms of trade. Hamada et al. [19] (p.761) affirm that 'since the mid-1950 many authors have discussed the measurement of the effect of changes in the terms of trade on real income.' In 1960, [43] proposed an adjustment procedure for assessing the effected of changes in the terms of trade on national income and product. His adjustment has the advantage of being specifically designed for the adjustment of net income (rather than production that other methods attempt to adjust) and it does not include quantity changes which facilitate the comparison with the expected gains. These reasons justify the choice of this method among the available in the literature. For a discussion of the alternatives see Hamada et al. [19]. His adjustment formula for income gains/loss, taken here from Hamada et al. [19], ignores net property income from abroad and can be expressed as:

$$
E^{t}\left(\frac{P_{E}^{t}}{P_{M}^{t}}-\frac{P_{E}^{t-1}}{P_{M}^{t-1}}\right)
$$

where $E^{t}$ are exports in the current year $t$ and, $P_{E}$ and $P_{M}$ denote exports and imports deflator respectively, thus the ratio $P_{E} / P_{M}$ corresponds to the terms of trade.

Employing this equation, Tables 1 and 2 present evidence on how much the terms of trade fluctuations actually affect estimates of national income and contrast these results with the expected gains from the terms of trade assumed by the imputed income method. The results are shown as the percentage adjustment in income 
(NNP). Within each table, Panel a examines the relevant periods by decade averages, while Panel $b$ divides the years into periods based on broad trends (such as peak-to-trough movements) in the terms of trade. This second Panel magnifies the possible effects of the terms of trade on measured income in the case of the actual effect figures. The first line of each table describes the importance of trade in the economy. It is evident from this line that the share of exports in Venezuela's income is much important than that of Mexico. This is relevant because as Spraos [57] revealed the effects of the changes in the terms of trade on income are more important the higher the proportion of income that is derived from exports.

By decades, the adjustment is most significant in the 1970s and the 1980s but with opposite signs. The figures for the terms of trade adjustment may be interpreted as follows: if the increase in the terms of trade from 1970 to 1979 is taken into account, then the recorded national income in 1979 understates the level of Venezuela's income by about 7.2 percent. Similarly, the decline in the terms of trade of the $1980 \mathrm{~s}$ means that the national income in 1989 overstates the level of Mexico's income by about 1 percent.

In looking at broad trends in the terms of trade (Panel b), the adjustment is also important (about 2 percent) for the period 1943-1957 for Venezuela, and the effects of the changes in the terms of trade of the oil boom and oil crisis are considerably magnified for both countries. These findings may lead economic historians to revise, at the margin, their interpretation of parts of the century. As a consequence of the terms of trade improvements, it appears that income increased much more than suggested by conventional estimates of national income during the 1970s. Likewise, the 1980s saw stronger losses in income than national accounts data suggested because of the sharp deterioration of the terms of trade during the what it has been called in Latin-American historiography the 'lost decade'. 
Table 1: Terms of Trade Effects on Venezuela's National Income (all figures as percentage of NNP)

\begin{tabular}{lrrrrrr}
\hline & \multicolumn{7}{c}{ Panel a } & & & \\
& $\mathbf{1 9 3 6 - 1 9 3 9}$ & $\mathbf{1 9 4 0 - 1 9 4 9}$ & $\mathbf{1 9 5 0 - 1 9 5 9}$ & $\mathbf{1 9 6 0 - 1 9 6 9}$ & $\mathbf{1 9 7 0 - 1 9 7 9}$ & $\mathbf{1 9 8 0 - 1 9 8 5}$ \\
\hline \hline Share of exports & $32.4 \%$ & $28.0 \%$ & $32.2 \%$ & $29.7 \%$ & $31.2 \%$ & $27.4 \%$ \\
Expected effect & $13.5 \%$ & $17.2 \%$ & $18.3 \%$ & $15.4 \%$ & $23.3 \%$ & $41.4 \%$ \\
Actual effect & $0.3 \%$ & $1.1 \%$ & $1.3 \%$ & $0.0 \%$ & $7.2 \%$ & $-2.5 \%$ \\
& \multicolumn{7}{c}{ Panel b } & & & \\
& $\mathbf{1 9 3 6 - 1 9 4 2}$ & $\mathbf{1 9 4 3 - 1 9 5 7}$ & $\mathbf{1 9 5 8 - 1 9 7 2}$ & $\mathbf{1 9 7 3 - 1 9 8 1}$ & $\mathbf{1 9 8 2 - 1 9 8 5}$ & $\mathbf{1 9 3 6 - 1 9 8 5}$ \\
\hline \hline Share of exports & $32.8 \%$ & $29.4 \%$ & $29.2 \%$ & $32.6 \%$ & $26.1 \%$ & $30.1 \%$ \\
Expected effect & $15.2 \%$ & $17.9 \%$ & $14.9 \%$ & $30.3 \%$ & $43.7 \%$ & $20.9 \%$ \\
Actual effect & $0.1 \%$ & $2.0 \%$ & $-0.3 \%$ & $9.9 \%$ & $-8.3 \%$ & $1.7 \%$ \\
& \multicolumn{7}{c}{}
\end{tabular}

Sources: The expected effect on income from expected improvements in the terms of trade corresponds to the second term $(\mathrm{Vt}(\mathrm{i} /(1+\mathrm{i}))$ of Sefton and Weale's equation. The actual effect on income from changes in terms of trade calculated using Nicholson's method defined in equation [3] with data on exports as in Appendix B and terms of trade as in Figure 3. The sources of the NNP are listed in Appendix D.

Table 2: Terms of Trade Effects on Mexico's National Income (all figures as percentage of NNP)

\begin{tabular}{lrrrr}
\hline & \multicolumn{4}{c}{ Panel a } \\
& $\mathbf{1 9 6 0 - 1 9 6 9}$ & $\mathbf{1 9 7 0 - 1 9 7 9}$ & $\mathbf{1 9 8 0 - 1 9 8 9}$ & $\mathbf{1 9 6 0 - 1 9 8 9}$ \\
\hline \hline Share of exports & $6 \%$ & $5 \%$ & $14 \%$ & $8 \%$ \\
Expected effect & $0.1 \%$ & $1.8 \%$ & $26.9 \%$ & $9.6 \%$ \\
Actual effect & $0.1 \%$ & $0.1 \%$ & $-1.0 \%$ & $-0.3 \%$ \\
& & & & \\
& & Panel b & & \\
& $\mathbf{1 9 6 0 - 1 9 7 3}$ & $\mathbf{1 9 7 4 - 1 9 8 1}$ & $\mathbf{1 9 8 2 - 1 9 8 6}$ & $\mathbf{1 9 8 7 - 1 9 8 9}$ \\
\hline \hline Share of exports & $5 \%$ & $6 \%$ & $16 \%$ & $15 \%$ \\
Expected effect & $0.0 \%$ & $7.8 \%$ & $34.6 \%$ & $17.3 \%$ \\
Actual effect & $0.0 \%$ & $0.6 \%$ & $-2.6 \%$ & $0.6 \%$ \\
& & & & \\
\hline
\end{tabular}

Sources: The expected effect corresponds to the second term $(\mathrm{Vt}(\mathrm{i} /(1+\mathrm{i}))$ of Sefton and Weale's adjustment. The actual effect on income from changes in terms of trade calculated using Nicholson's method defined in equation [3] with data on exports as in Appendix B and terms of trade as in Figure 4. The sources of the NNP are listed in Appendix D. 
All in all, the actual effect on income from the terms of trade is much smaller than the imputed income for each and every period. This is also true for the whole period: an actual gain of 1.7 percent contrasts with the expected gain of 20.9 percent for the period 1936-1985 for Venezuela, and for Mexico an expected gain of 9.6 per cent contrasts with an actual loss of -0.3 percent for the period 1960-1989. The terms of trade do not appear to have helped oil producers over the long run as much as some theoretical models predict. We can now re-calculate the $Z$ indicator taking into account the effects on income from the actual changes in the terms of trade. Figures 9 and 10 display the results.

Contrary to the results obtained using the expected gains from trade, the additions to income due to the historical changes in the terms of trade do not suffice to compensate for the depletion of oil reserves, resulting in the return of the paradox of negative genuine savings for over 30 years in the case of Venezuela and yet no observable decline in well-being. The Mexican indicator also improves slightly as a consequence of the effects of the terms of trade, but it still remains negative for the early 1980 s.

Following Irwin [27] at least two caveats should be noted to this section. First, the analysis presented here presumes that an increase in the relative price of exportables, an improvement in the terms of trade, is also an improvement from some welfare standpoint. Although Krueger et al. [28] established this presumption, simple connections between the terms of trade and national income or economic welfare cannot necessarily be drawn. In words of Irwin, 'a tariff that improves the terms of trade, for example, may no increase national income if it reduces the volume of trade excessively.' Second, the figures for NNP and savings are estimates and their precision should not be overstated. Thus, the figures presented here should be considered merely illustrative of the impacts of the terms of trade and depreciation of natural capital on national income. 
Figure 9: Genuine Savings Taking into Account the Actual Gains from Trade. Venezuela 1936-1985 (percentage over traditional GDP)

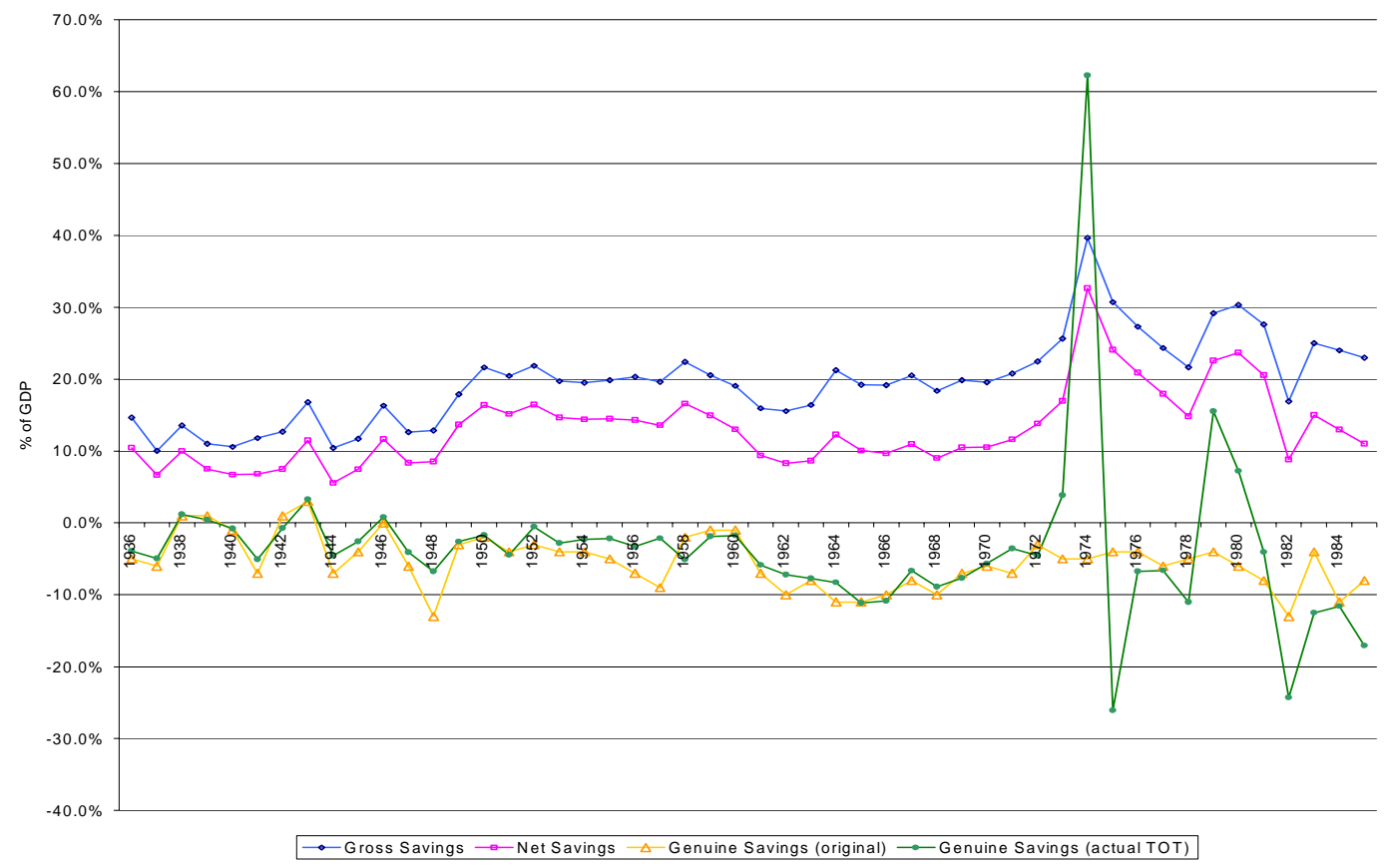

Sources: Gross and net savings as in Figure 1. Genuine savings correspond to the NNP (Appendix D) twice adjusted: firstly by the effects of the changes in the terms of trade calculated in Table 1 and secondly the corresponding natural capital depreciation was deducted.

Figure 10: Genuine Savings Taking into Account the Actual Gains from Trade. Mexico 1950-1985 (percentage over traditional GDP)

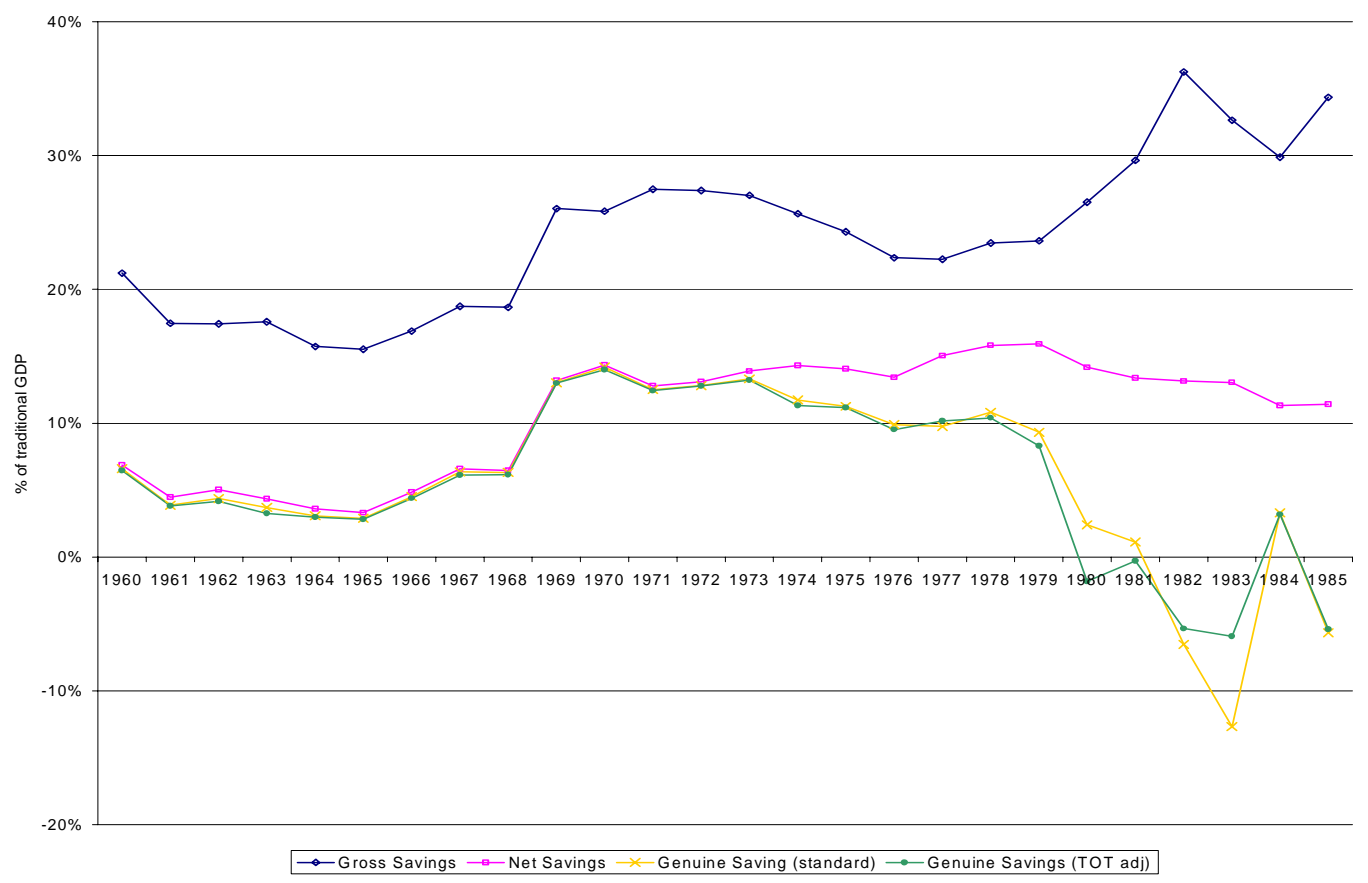

Sources: Gross and net savings as in Figure 2. Genuine savings correspond to the NNP as listed in Appendix D twice adjusted: firstly by the effects of the changes in the terms of trade calculated in Table 2 and secondly the corresponding natural capital depreciation was deducted. 
This paper has explored the first of two theoretical objections to the $Z>0$ rule: the role of capital gains arising from improved terms of trade. It has been shown that although theoretically it can be expected that the gains from improved terms of trade more than compensate for the cost of depleting oil resources, thus guaranteeing the future consumption of an oil exporter country, the historical changes in the terms of trade do not correspond to the theoretical expectations. The historical evolution of the terms of trade do not suffice to explain why Mexico and in particular Venezuela have enjoyed non-declining consumption levels despite consuming most of the rents generated by oil extraction. The terms of trade influenced income, but much less than expected, being even negative in some instances. The results show that the role of technological change in sustaining the historical levels of consumption may be substantial since the terms of trade did not improve in the continuous way needed to rescue the two economies from declining levels of consumption. This is an important finding because while gains from trade have now been included in some environmental accounting models, technological change is left out.

As expected by environmental accountants, income differs when natural resources are included in national accounts. But traditional income estimates do not always exaggerate income as standard environmental accounting predicts once the effects of the terms of trade are considered. This should not discourage environmental accountants for it implies that the misfit between traditional and environmentally adjusted income is even greater than simple theoretical models predicted. Traditional measures of income can no longer be considered either a reliable indicator of sustainable income or the future consumption possibilities of the economy.

A final remark applies to all the exercises in this paper. The analyst should bear in mind that savings are for the most part a residual value calculated from the macro economic data which sources are in Appendix D, that in the calculation of the resource rent average and not marginal costs have been used and that most of the traditional macro indicators used in the calculations are also estimates. Nevertheless, the overall message of the paper seems robust enough even when the figures provided are not as precise as desired. 
Table 3: Genuine Savings Indicator Including Terms of Trade Effects. Summary of Venezuelan results 1936-1985.

\begin{tabular}{|c|c|c|c|c|c|c|c|c|}
\hline \multirow[b]{3}{*}{ Year } & \multicolumn{4}{|c|}{ Genuine Savings Standard Index } & \multicolumn{4}{|c|}{ Terms of Trade Effects } \\
\hline & & & & & Expe & ected & Act & tual \\
\hline & $\begin{array}{c}(1) \\
\text { NNDadj }\end{array}$ & $\begin{array}{c}\text { Gross } \\
\text { savings }\end{array}$ & $\begin{array}{c}\text { Net } \\
\text { savings }\end{array}$ & $\begin{array}{c}(1) \\
Z\end{array}$ & $\begin{array}{c}(2 \mathrm{a}) \\
\text { NNDadj }\end{array}$ & $\begin{array}{c}(2 \mathrm{a}) \\
\mathrm{Z}\end{array}$ & $\begin{array}{c}(2 \mathrm{~b}) \\
\text { NNDadj }\end{array}$ & $\begin{array}{c}(2 \mathrm{~b}) \\
\mathrm{Z}\end{array}$ \\
\hline & $\%$ of NNPtrad & $\%$ of GDPtrad & $\%$ of GDPtrad & $\%$ of GDPtrad & $\%$ of NNPtrad & $\%$ of GDPtrad & $\%$ of NNPtrad & $\%$ of GDPtrad \\
\hline 1936 & 83.3 & 14.7 & 10.5 & -5.0 & 101.7 & 11.9 & 83.4 & -3.9 \\
\hline 1937 & 85.7 & 10.1 & 6.7 & -6.0 & 101.5 & 8.0 & 86.7 & -5.0 \\
\hline 1938 & 89.9 & 13.6 & 10.0 & 1.0 & 101.1 & 11.0 & 90.2 & 1.2 \\
\hline 1939 & 92.2 & 11.0 & 7.5 & 1.0 & 100.9 & 8.3 & 92.1 & 0.4 \\
\hline 1940 & 91.2 & 10.6 & 6.7 & -1.0 & 105.3 & 11.5 & 91.7 & -0.8 \\
\hline 1941 & 84.7 & 11.8 & 6.8 & -7.0 & 106.3 & 12.1 & 85.9 & -5.1 \\
\hline 1942 & 93.0 & 12.7 & 7.5 & 1.0 & 109.7 & 16.2 & 90.9 & -0.7 \\
\hline 1943 & 90.5 & 16.8 & 11.5 & 3.0 & 110.2 & 20.8 & 91.0 & 3.3 \\
\hline 1944 & 86.7 & 10.4 & 5.6 & -7.0 & 105.9 & 10.7 & 88.4 & -4.5 \\
\hline 1945 & 87.8 & 11.7 & 7.5 & -4.0 & 102.6 & 9.8 & 88.8 & -2.6 \\
\hline 1946 & 86.4 & 16.3 & 11.6 & 0.0 & 100.5 & 12.1 & 87.7 & 0.8 \\
\hline 1947 & 83.7 & 12.6 & 8.3 & -6.0 & 98.9 & 7.4 & 85.7 & -4.1 \\
\hline 1948 & 76.6 & 12.8 & 8.5 & -13.0 & 96.8 & 5.8 & 82.1 & -6.7 \\
\hline 1949 & 82.1 & 17.9 & 13.7 & -3.0 & 98.9 & 12.7 & 81.8 & -2.6 \\
\hline 1950 & 78.7 & 21.6 & 16.4 & -2.0 & 97.3 & 14.0 & 79.3 & -1.7 \\
\hline 1951 & 78.5 & 20.5 & 15.1 & -4.0 & 95.6 & 11.4 & 77.5 & -4.4 \\
\hline 1952 & 77.7 & 21.9 & 16.5 & -3.0 & 94.7 & 11.9 & 80.5 & -0.5 \\
\hline 1953 & 79.1 & 19.7 & 14.7 & -4.0 & 97.0 & 12.0 & 80.2 & -2.8 \\
\hline 1954 & 79.5 & 19.5 & 14.4 & -4.0 & 97.0 & 11.8 & 81.1 & -2.3 \\
\hline 1955 & 77.7 & 19.9 & 14.5 & -5.0 & 96.7 & 11.6 & 81.0 & -2.2 \\
\hline 1956 & 76.1 & 20.3 & 14.3 & -7.0 & 96.0 & 10.9 & 79.4 & -3.3 \\
\hline 1957 & 74.2 & 19.6 & 13.6 & -9.0 & 95.5 & 9.8 & 81.4 & -2.1 \\
\hline 1958 & 79.6 & 22.4 & 16.6 & -2.0 & 98.9 & 15.6 & 75.5 & -5.1 \\
\hline 1959 & 82.7 & 20.6 & 15.0 & -1.0 & 98.4 & 13.5 & 81.3 & -1.9 \\
\hline 1960 & 83.7 & 19.1 & 13.0 & -1.0 & 98.4 & 11.6 & 83.3 & -1.7 \\
\hline 1961 & 82.1 & 15.9 & 9.4 & -7.0 & 97.5 & 7.1 & 82.5 & -5.8 \\
\hline 1962 & 80.1 & 15.6 & 8.3 & -10.0 & 95.5 & 4.5 & 81.9 & -7.2 \\
\hline 1963 & 81.2 & 16.4 & 8.7 & -8.0 & 95.7 & 5.0 & 80.8 & -7.7 \\
\hline 1964 & 73.8 & 21.3 & 12.3 & -11.0 & 93.4 & 6.7 & 75.6 & -8.3 \\
\hline 1965 & 75.8 & 19.2 & 10.1 & -11.0 & 93.5 & 4.6 & 74.7 & -11.1 \\
\hline 1966 & 77.3 & 19.1 & 9.7 & -10.0 & 94.0 & 4.6 & 75.6 & -10.8 \\
\hline 1967 & 77.9 & 20.5 & 11.0 & -8.0 & 92.5 & 4.7 & 79.2 & -6.6 \\
\hline 1968 & 78.6 & 18.4 & 9.0 & -10.0 & 92.2 & 2.5 & 78.8 & -8.9 \\
\hline 1969 & 80.5 & 19.9 & 10.5 & -7.0 & 92.4 & 4.0 & 78.8 & -7.7 \\
\hline 1970 & 81.5 & 19.6 & 10.5 & -6.0 & 91.6 & 3.2 & 81.3 & -5.7 \\
\hline 1971 & 78.8 & 20.8 & 11.6 & -7.0 & 90.9 & 3.8 & 82.3 & -3.5 \\
\hline 1972 & 81.4 & 22.5 & 13.8 & -3.0 & 92.9 & 7.5 & 79.3 & -4.5 \\
\hline 1973 & 75.3 & 25.6 & 17.0 & -5.0 & 94.8 & 12.4 & 85.1 & 3.8 \\
\hline 1974 & 58.6 & 39.7 & 32.7 & -5.0 & 95.2 & 28.3 & 132.4 & 62.3 \\
\hline 1975 & 69.4 & 30.7 & 24.1 & -4.0 & 102.7 & 26.6 & 46.1 & -26.1 \\
\hline 1976 & 73.4 & 27.3 & 20.9 & -4.0 & 102.3 & 23.0 & 70.4 & -6.7 \\
\hline 1977 & 74.7 & 24.3 & 18.0 & -6.0 & 102.3 & 20.1 & 73.7 & -6.6 \\
\hline 1978 & 78.9 & 21.7 & 14.8 & -5.0 & 102.5 & 17.1 & 72.1 & -11.0 \\
\hline 1979 & 71.1 & 29.2 & 22.6 & -4.0 & 101.1 & 23.6 & 92.4 & 15.5 \\
\hline 1980 & 68.1 & 30.3 & 23.7 & -6.0 & 105.0 & 28.3 & 82.3 & 7.2 \\
\hline 1981 & 69.2 & 27.6 & 20.6 & -8.0 & 106.0 & 26.1 & 73.3 & -4.1 \\
\hline 1982 & 75.6 & 16.9 & 8.8 & -13.0 & 114.1 & 21.5 & 63.1 & -24.3 \\
\hline 1983 & 78.6 & 25.0 & 15.0 & -4.0 & 115.7 & 28.0 & 69.1 & -12.5 \\
\hline 1984 & 72.6 & 24.0 & 13.0 & -11.0 & 125.0 & 34.5 & 72.0 & -11.6 \\
\hline 1985 & 77.9 & 23.0 & 11.0 & -8.0 & 124.6 & 32.1 & 67.2 & -17.1 \\
\hline
\end{tabular}

Sources and notes: traditional indicators as in Appendix D. Insufficient data for the calculation marked n.a. (1) $\mathrm{NNP}_{\text {adj }}=\mathrm{NNP}_{\text {trad }}-\mathrm{N}_{\mathrm{t}}$ (net price adjustment) as in Table A.1.

(2a) $\mathrm{NNP}_{\mathrm{adj}}=\mathrm{NNP}_{\text {trad }}-\left(\mathrm{N}_{\mathrm{t}}+(\mathrm{i} / \mathrm{i}+1) \mathrm{V}_{\mathrm{t}}\right)$ for $\mathrm{V}_{\mathrm{t}}=\mathrm{uQ}$ imputed income adjustment as in Table A.4.

(2b) $\mathrm{NNP}_{\mathrm{adj}}=\mathrm{NNP}_{\text {trad }}-\left(\mathrm{N}_{\mathrm{t}}+\mathrm{TOT}\right)$ for TOT corresponds to the adjustment for the terms of trade in Table 1. 
Table 4: Genuine Savings Indicator Including Terms of Trade Effects. Summary of Mexican results 1950-1985.

\begin{tabular}{|c|c|c|c|c|c|c|c|c|}
\hline \multirow[b]{3}{*}{ Year } & \multicolumn{4}{|c|}{ Genuine Savings Standard Index } & \multicolumn{4}{|c|}{ Terms of Trade Effects } \\
\hline & \multirow[b]{2}{*}{$\begin{array}{c}(1) \\
\text { NNDadj } \\
\% \text { of NNPtrad }\end{array}$} & \multirow[b]{2}{*}{$\begin{array}{c}\text { Gross } \\
\text { savings } \\
\% \text { of GDPtrad } \\
\end{array}$} & \multirow[b]{2}{*}{$\begin{array}{c}\text { Net } \\
\text { savings } \\
\text { \% of GDPtrad }\end{array}$} & \multirow[b]{2}{*}{$\begin{array}{c}\text { (1) } \\
\mathrm{Z} \\
\text { \% of GDPtrad }\end{array}$} & \multicolumn{2}{|c|}{ Expected } & \multicolumn{2}{|c|}{ Actual } \\
\hline & & & & & \begin{tabular}{c|}
$(2 a)$ \\
NNDadj \\
$\%$ of NNPtrad
\end{tabular} & $\begin{array}{c}\text { (2a) } \\
\mathrm{Z} \\
\text { \% of GDPtrad }\end{array}$ & \begin{tabular}{|c|}
$(2 b)$ \\
NNDadj \\
$\%$ of NNPtrad
\end{tabular} & 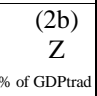 \\
\hline 1950 & 98.0 & 20.3 & 7.1 & 5.5 & 98.3 & 5.7 & n.a & n.a \\
\hline 1951 & 98.2 & 18.4 & 5.4 & 3.9 & 98.4 & 4.0 & n.a & n.a \\
\hline 1952 & 98.2 & 20.6 & 7.4 & 5.9 & 98.6 & 6.2 & n.a & n.a \\
\hline 1953 & 98 & 18.6 & 5.3 & 4.3 & 98. & 4.3 & n.a & n.a \\
\hline 1954 & 98.5 & 20.4 & 7.6 & 6.4 & 98.6 & 6.4 & n.a & n.a \\
\hline 1955 & 98.7 & 21.4 & 8.8 & 7.8 & 98.8 & 7.8 & n.a & n.a \\
\hline 1956 & 98.8 & & & 7.8 & 98.9 & 7.8 & n.a & n.a \\
\hline 1957 & 98.6 & 19.8 & 7.0 & 5.9 & 98.7 & 5.9 & n.a & n.a \\
\hline 1958 & 98.9 & 19.0 & 6.3 & 5.5 & 98.9 & 5.4 & n.a & n.a \\
\hline 1959 & 99 & 19.7 & 6 & 6.3 & 99 & 6.2 & .a & n.a \\
\hline 1960 & 99.5 & 21.2 & 6 & 6.6 & 99.5 & 6.5 & 99.5 & 6.5 \\
\hline 1961 & 99 & 17 & 4 & 3.9 & 99. & 3. & 99.2 & 3.8 \\
\hline 1962 & 99. & 17.4 & 5 & 4.4 & 99.1 & 4.4 & 98.9 & 4.2 \\
\hline 1963 & 99.1 & 17.6 & 4 & 3.7 & 99.2 & 3.7 & 98.7 & 3.3 \\
\hline 1964 & 99. & & 3 & 3.1 & 99. & 3.1 & 99.3 & 3.0 \\
\hline 1965 & 99.4 & 15.5 & 3 & 2.9 & 99.4 & 2.9 & 99.4 & 2.8 \\
\hline 1966 & 99. & 16. & 4.8 & 4.5 & 99.6 & 4. & 99.5 & 4.4 \\
\hline 1967 & 99 & 18 & 6.6 & 6.4 & 99.6 & 6. & 99.5 & 6.1 \\
\hline 1968 & 99.7 & 18.7 & 6.5 & 6.3 & 99.7 & 6.2 & 99.6 & 6.2 \\
\hline 1969 & 99.7 & 26.0 & & 13.0 & 99.7 & 12.9 & 99.8 & 13.0 \\
\hline 1970 & 99.7 & & & & 99.8 & 14.1 & 99.6 & 14.0 \\
\hline 1971 & 99.6 & 27.5 & 12 & 12.5 & 99.6 & 12.4 & 99.6 & 12.4 \\
\hline 1972 & 99 & 27. & 13.1 & 12.8 & 99.6 & 12.7 & 99.7 & 12.8 \\
\hline 1973 & 99.3 & 27. & 13.9 & 13.3 & 99.3 & 13.2 & 99.3 & 13.2 \\
\hline 1974 & 97.1 & 25.7 & 14.3 & 11.7 & 97.2 & 11.7 & 96.8 & 11.3 \\
\hline 1975 & 96.9 & 24.3 & 14.1 & 11.3 & 97.2 & 11.5 & 96.9 & 11.2 \\
\hline 1976 & 96.0 & 22.4 & & 9.9 & 96.7 & 10.4 & 95.8 & 9.5 \\
\hline 1977 & 94.1 & 22.3 & 15 & 9.8 & 95.7 & 11.0 & 94.7 & 10.2 \\
\hline 1978 & 94.3 & 23.5 & 15.8 & 10.8 & 100.6 & 16.4 & 94.1 & 10.4 \\
\hline 1979 & 92.5 & 23.6 & 15.9 & 9.3 & 101.9 & 17.7 & 91.7 & 8.3 \\
\hline 1980 & 86.8 & 26.5 & 14.2 & 2.4 & 106.9 & 19.7 & 83.5 & -1.8 \\
\hline 1981 & 86.2 & 29.6 & 13 & 1.1 & 110.0 & 21.9 & 85.7 & -0.3 \\
\hline 1982 & 77.3 & 36.3 & 13.1 & -6.5 & 116.1 & 27.3 & 79.0 & -5.3 \\
\hline 1983 & 69.9 & 32.6 & 13.1 & -12.7 & 126.8 & 36.0 & 77.8 & -5.9 \\
\hline 1984 & 90.5 & 29.9 & 11.3 & 3.3 & 108.2 & 18.4 & 90.5 & 3.2 \\
\hline 1985 & 79.8 & 34.4 & 11.4 & -5.7 & 116.4 & 25.1 & 80.4 & -5.4 \\
\hline
\end{tabular}

Sources and notes: traditional indicators as in Appendix D. Insufficient data for the calculation marked n.a. (1) $\mathrm{NNP}_{\mathrm{adj}}=\mathrm{NNP}_{\text {trad }}-\mathrm{N}_{\mathrm{t}}$, net price adjustment as in Table A.2.

(2a) $\mathrm{NNP}_{\mathrm{adj}}=\mathrm{NNP}_{\text {trad }}-\left(\mathrm{N}_{\mathrm{t}}+(\mathrm{i} / \mathrm{i}+1) \mathrm{V}_{\mathrm{t}}\right)$ for $\mathrm{V}_{\mathrm{t}}=\mathrm{uQ}$, imputed income adjustment as in Table A.4.

(2b) $\mathrm{NNP}_{\mathrm{adj}}=\mathrm{NNP}_{\text {trad }}-\left(\mathrm{N}_{\mathrm{t}}+\mathrm{TOT}\right)$ for TOT corresponds to the adjustment for the terms of trade in Table 2. 
Gains from Trade Are Not Enough

APPENDIX 1

\begin{tabular}{|c|c|c|c|}
\hline \multicolumn{4}{|c|}{ Table A.1: Venezuelan resource rent through time, 1920-1985 } \\
\hline \multirow{2}{*}{ Year } & \multirow{2}{*}{$\begin{array}{c}\text { Aggregated rent, } N \\
\text { Mll. Blv. }\end{array}$} & \multicolumn{2}{|c|}{ Rent per unit, $u$} \\
\hline & & Bolivars & As \% of price per barrel \\
\hline 1920 & -4.8 & -9.5 & \\
\hline 1921 & -5.1 & -3.7 & \\
\hline 1922 & -3.7 & -1.7 & \\
\hline 1923 & 4.4 & 1.0 & $13 \%$ \\
\hline 1924 & 31.5 & 3.5 & $39 \%$ \\
\hline 1925 & 98.4 & 4.9 & $54 \%$ \\
\hline 1926 & 206.0 & 5.8 & $62 \%$ \\
\hline 1927 & 218.4 & 3.6 & $56 \%$ \\
\hline 1928 & 375.2 & 3.5 & $67 \%$ \\
\hline 1929 & 581.7 & 4.3 & $71 \%$ \\
\hline 1930 & 608.2 & 4.5 & $73 \%$ \\
\hline 1931 & 332.1 & 2.8 & $66 \%$ \\
\hline 1932 & 496.3 & 4.3 & $77 \%$ \\
\hline 1933 & 176.2 & 1.5 & $54 \%$ \\
\hline 1934 & 303.6 & 2.2 & $67 \%$ \\
\hline 1935 & 332.7 & 2.2 & $68 \%$ \\
\hline 1936 & 362.7 & 2.3 & $68 \%$ \\
\hline 1937 & 384.5 & 2.1 & $65 \%$ \\
\hline 1938 & 293.0 & 1.6 & $54 \%$ \\
\hline 1939 & 238.1 & 1.2 & $47 \%$ \\
\hline 1940 & 257.5 & 1.4 & $49 \%$ \\
\hline 1941 & 426.7 & 1.9 & $62 \%$ \\
\hline 1942 & 188.2 & 1.3 & $41 \%$ \\
\hline 1943 & 295.0 & 1.6 & $52 \%$ \\
\hline 1944 & 513.8 & 2.0 & $62 \%$ \\
\hline 1945 & 648.2 & 2.0 & $61 \%$ \\
\hline 1946 & 905.6 & 2.3 & $60 \%$ \\
\hline 1947 & $1,502.3$ & 3.5 & $64 \%$ \\
\hline 1948 & $2,556.7$ & 5.2 & $70 \%$ \\
\hline 1949 & $2,200.9$ & 4.6 & $66 \%$ \\
\hline 1950 & $2,561.0$ & 4.7 & $72 \%$ \\
\hline 1951 & $2,754.2$ & 4.4 & $72 \%$ \\
\hline 1952 & $3,123.1$ & 4.7 & $72 \%$ \\
\hline 1953 & $3,284.9$ & 5.1 & $72 \%$ \\
\hline 1954 & $3,593.7$ & 5.2 & $73 \%$ \\
\hline 1955 & $4,316.1$ & 5.5 & $76 \%$ \\
\hline 1956 & $4,956.6$ & 5.5 & $76 \%$ \\
\hline 1957 & $6,277.0$ & 6.2 & $76 \%$ \\
\hline 1958 & $5,261.6$ & 5.5 & $72 \%$ \\
\hline 1959 & $4,789.4$ & 4.7 & $69 \%$ \\
\hline 1960 & $4,572.1$ & 4.4 & $67 \%$ \\
\hline 1961 & $4,907.0$ & 4.6 & $70 \%$ \\
\hline 1962 & $5,592.0$ & 4.8 & $75 \%$ \\
\hline 1963 & $5,550.4$ & 4.7 & $75 \%$ \\
\hline 1964 & $8,653.4$ & 7.0 & $82 \%$ \\
\hline 1965 & $8,551.9$ & 6.7 & $82 \%$ \\
\hline 1966 & $8,295.8$ & 6.7 & $82 \%$ \\
\hline 1967 & $8,671.7$ & 6.7 & $82 \%$ \\
\hline 1968 & $8,990.5$ & 6.8 & $83 \%$ \\
\hline 1969 & $8,663.9$ & 6.6 & $83 \%$ \\
\hline 1970 & $9,088.4$ & 6.7 & $83 \%$ \\
\hline 1971 & $11,385.9$ & 8.8 & $86 \%$ \\
\hline 1972 & $11,143.4$ & 9.5 & $87 \%$ \\
\hline 1973 & $17,178.3$ & 14.0 & $90 \%$ \\
\hline 1974 & $45,686.0$ & 42.1 & $95 \%$ \\
\hline 1975 & $36,840.9$ & 43.0 & $93 \%$ \\
\hline 1976 & $37,409.2$ & 44.6 & $94 \%$ \\
\hline 1977 & $41,662.7$ & 51.1 & $95 \%$ \\
\hline 1978 & $37,662.5$ & 47.7 & $93 \%$ \\
\hline 1979 & $62,337.5$ & 72.5 & $94 \%$ \\
\hline 1980 & $83,690.1$ & 105.5 & $93 \%$ \\
\hline 1981 & $90,320.7$ & 117.5 & $92 \%$ \\
\hline 1982 & $72,278.0$ & 104.6 & $89 \%$ \\
\hline 1983 & $60,657.9$ & 92.3 & $85 \%$ \\
\hline 1984 & $93,405.6$ & 141.7 & $89 \%$ \\
\hline 1985 & $82,187.4$ & 134.1 & $86 \%$ \\
\hline
\end{tabular}

Sources and notes: $N_{t}=p q-r k-c l$, that is the resource rent is the residual to the owner after discounting capital and labour costs from the gross revenue. Elaborated from the data in Appendixes A, F, G and $\mathrm{H}$. A return of 15 per cent on capital invested in the oil sector was allowed in this calculation. Several alternative calculations on the return to capital were tried and do not convey substantial changes to the final results. These can be found in Rubio [52]. 
Table A.2: Mexican resource rent through time, 1927-1987

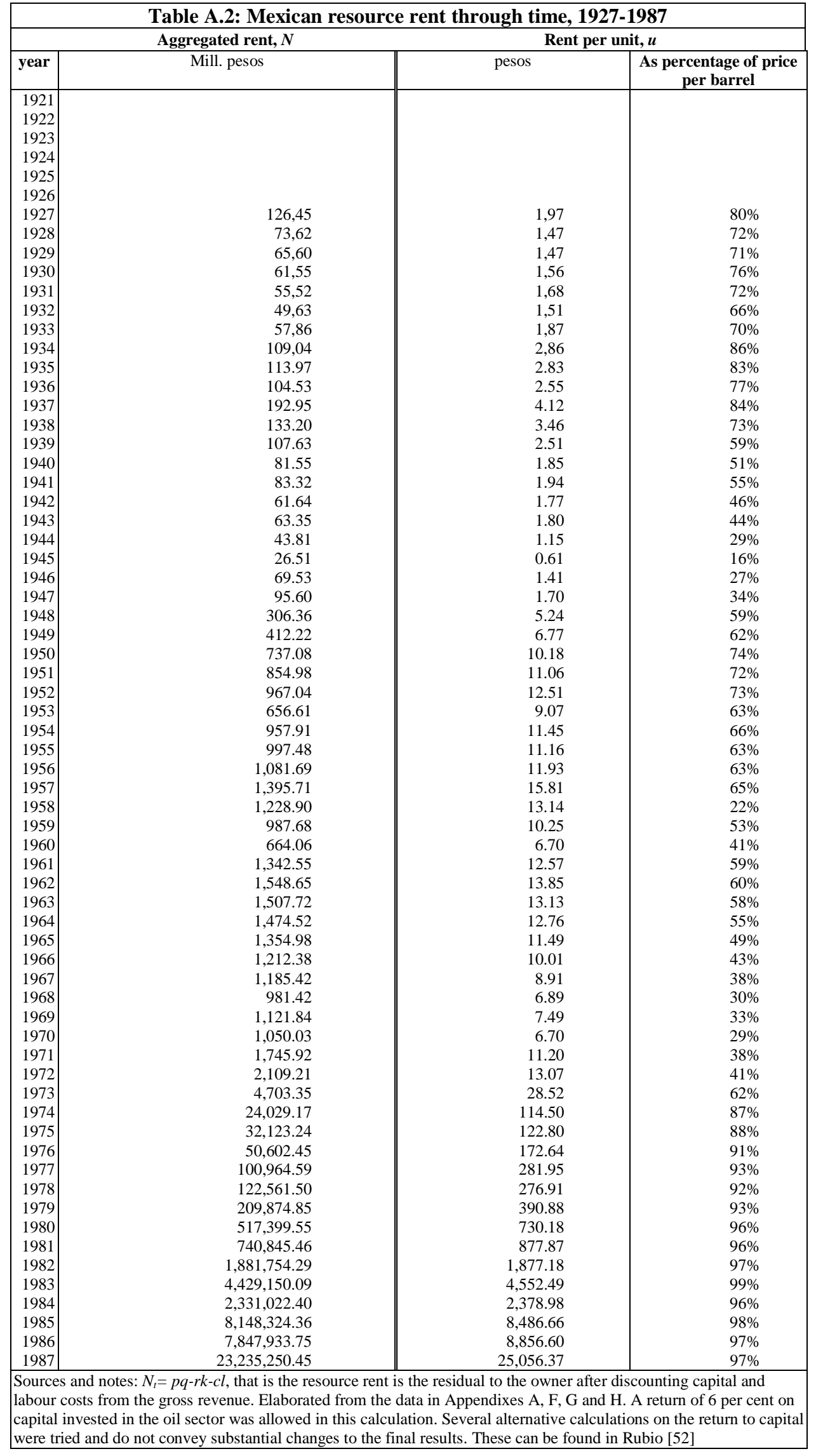


Gains from Trade Are Not Enough

Table A.3: Imputed value to the stock targeted for exports for Venezuela 1921-1985, Sefton and Weale Method. (negative figures in parentheses)

\begin{tabular}{|c|c|c|c|c|}
\hline \multirow[t]{2}{*}{ Year } & \multirow[t]{2}{*}{$V_{t}=u_{t} Q_{E}$} & \multicolumn{3}{|c|}{$-N_{t}+V_{t}(i / 1+i)$} \\
\hline & & $\mathrm{i}=3 \%$ & $i=6 \%$ & $\mathrm{i}=15 \%$ \\
\hline 1921 & $(149.08)$ & 0.77 & $(3.33)$ & $(14.34)$ \\
\hline 1922 & (140.54) & $(0.37)$ & (4.23) & (14.60) \\
\hline 1923 & 202.65 & 1.51 & 7.08 & 22.05 \\
\hline 1924 & $1,724.67$ & 18.71 & 66.10 & 193.43 \\
\hline 1925 & $2,446.21$ & $(27.15)$ & 40.07 & 220.67 \\
\hline 1926 & $4,194.66$ & $(83.80)$ & 31.46 & 341.15 \\
\hline 1927 & $3,464.23$ & (117.50) & $(22.31)$ & 233.45 \\
\hline 1928 & $4,246.87$ & (251.46) & (134.76) & 178.79 \\
\hline 1929 & $3,990.64$ & $(465.45)$ & $(355.79)$ & (61.16) \\
\hline 1930 & $5,328.35$ & (452.97) & $(306.56)$ & 86.84 \\
\hline 1931 & $3,540.41$ & (228.97) & (131.69) & 129.70 \\
\hline 1932 & $6,233.77$ & (314.70) & (143.41) & 316.84 \\
\hline 1933 & $2,547.60$ & (101.96) & (31.96) & 156.13 \\
\hline 1934 & $5,543.86$ & (142.09) & 10.25 & 419.56 \\
\hline 1935 & $6,429.00$ & (145.49) & 31.16 & 505.82 \\
\hline 1936 & $7,050.14$ & (157.37) & 36.35 & 556.87 \\
\hline 1937 & $7,519.11$ & (165.54) & 41.07 & 596.21 \\
\hline 1938 & $5,761.94$ & (125.19) & 33.14 & 458.55 \\
\hline 1939 & $4,709.35$ & (100.96) & 28.44 & 376.14 \\
\hline 1940 & $7,263.64$ & $(45.95)$ & 153.63 & 689.92 \\
\hline 1941 & $10,644.62$ & (116.71) & 175.78 & 961.68 \\
\hline 1942 & $7,928.94$ & 42.75 & 260.62 & 846.02 \\
\hline 1943 & $10,791.19$ & 19.30 & 315.82 & $1,112.54$ \\
\hline 1944 & $13,136.11$ & (131.17) & 229.78 & $1,199.63$ \\
\hline 1945 & $13,911.06$ & $(243.06)$ & 139.18 & $1,166.25$ \\
\hline 1946 & $16,569.10$ & $(423.00)$ & 32.28 & $1,255.59$ \\
\hline 1947 & $24,675.17$ & (783.58) & $(105.56)$ & $1,716.23$ \\
\hline 1948 & $39,011.97$ & $(1,420.46)$ & $(348.51)$ & $2,531.79$ \\
\hline 1949 & $36,461.71$ & $(1,138.86)$ & (136.98) & $2,555.02$ \\
\hline 1950 & $39,511.32$ & $(1,410.22)$ & (324.55) & $2,592.61$ \\
\hline 1951 & $38,786.71$ & $(1,624.50)$ & $(558.74)$ & $2,304.93$ \\
\hline 1952 & $42,138.92$ & $(1,895.72)$ & (737.84) & $2,373.31$ \\
\hline 1953 & $49,563.93$ & $(1,841.30)$ & $(479.40)$ & $3,179.95$ \\
\hline 1954 & $54,155.41$ & $(2,016.35)$ & $(528.29)$ & $3,470.06$ \\
\hline 1955 & $64,802.85$ & $(2,428.62)$ & $(648.00)$ & $4,136.46$ \\
\hline 1956 & $73,072.17$ & $(2,828.30)$ & $(820.46)$ & $4,574.54$ \\
\hline 1957 & $91,598.38$ & $(3,609.07)$ & $(1,092.18)$ & $5,670.63$ \\
\hline 1958 & $87,861.97$ & $(2,702.49)$ & $(288.26)$ & $6,198.68$ \\
\hline 1959 & $76,644.19$ & $(2,557.04)$ & $(451.05)$ & $5,207.67$ \\
\hline 1960 & $73,001.87$ & $(2,445.86)$ & (439.95) & $4,949.85$ \\
\hline 1961 & $74,373.97$ & $(2,740.73)$ & $(697.11)$ & $4,793.99$ \\
\hline 1962 & $76,710.32$ & $(3,357.75)$ & $(1,249.94)$ & $4,413.67$ \\
\hline 1963 & $75,832.04$ & $(3,341.74)$ & $(1,258.06)$ & $4,340.69$ \\
\hline 1964 & $114,054.70$ & $(5,331.45)$ & $(2,197.51)$ & $6,223.26$ \\
\hline 1965 & $110,532.69$ & $(5,332.48)$ & $(2,295.31)$ & $5,865.43$ \\
\hline 1966 & $107,730.95$ & $(5,157.97)$ & $(2,197.78)$ & $5,756.10$ \\
\hline 1967 & $101,568.39$ & $(5,713.44)$ & $(2,922.59)$ & $4,576.31$ \\
\hline 1968 & $101,106.42$ & $(6,045.65)$ & $(3,267.49)$ & $4,197.30$ \\
\hline 1969 & $93,133.68$ & $(5,951.31)$ & $(3,392.23)$ & $3,483.93$ \\
\hline 1970 & $87,447.84$ & $(6,541.37)$ & $(4,138.52)$ & $2,317.85$ \\
\hline 1971 & $115,111.21$ & $(8,033.12)$ & $(4,870.14)$ & $3,628.64$ \\
\hline 1972 & $121,395.17$ & $(7,607.67)$ & $(4,272.03)$ & $4,690.70$ \\
\hline 1973 & $239,467.92$ & $(10,203.47)$ & $(3,623.47)$ & $14,056.68$ \\
\hline 1974 & $713,399.88$ & $(24,907.35)$ & $(5,304.86)$ & $47,366.18$ \\
\hline 1975 & $708,383.56$ & $(16,208.35)$ & $3,256.30$ & $55,556.97$ \\
\hline 1976 & $717,854.94$ & $(16,500.85)$ & $3,224.05$ & $56,224.00$ \\
\hline 1977 & $802,217.38$ & $(18,297.18)$ & $3,745.80$ & $62,974.32$ \\
\hline 1978 & $742,623.13$ & $(16,032.70)$ & $4,372.77$ & $59,201.38$ \\
\hline 1979 & $1,144,123.63$ & $(29,013.55)$ & $2,424.18$ & $86,895.98$ \\
\hline 1980 & $1,709,050.38$ & $(33,911.98)$ & $13,048.55$ & $139,229.47$ \\
\hline 1981 & $1,906,609.75$ & $(34,788.37)$ & $17,600.62$ & $158,367.53$ \\
\hline 1982 & $2,014,999.75$ & $(13,588.65)$ & $41,778.63$ & $190,548.09$ \\
\hline 1983 & $1,859,640.38$ & $(6,493.59)$ & $44,604.80$ & $181,903.91$ \\
\hline 1984 & $3,153,399.75$ & $(1,559.03)$ & $85,088.70$ & $317,907.38$ \\
\hline 1985 & $3,065,309.50$ & $7,093.42$ & $91,320.66$ & $317,635.53$ \\
\hline
\end{tabular}

$N_{t}$ as in Table A.1

$\mathrm{Q}_{\mathrm{E}}$ is the stock targeted for exports 'assuming the ratio of the domestic utilisation of the resource to foreign utilisation remains constant'. Data derived from the data in Appendix A. 
Table A.4: Imputed value to the stock targeted for exports. Mexico 1935-1985 Sefton and Weale Method. (negative figures in parentheses)

\begin{tabular}{|c|c|c|c|c|}
\hline \multirow[t]{2}{*}{ Year } & \multirow[t]{2}{*}{$V_{t}=u_{t} Q_{E}$} & \multicolumn{3}{|c|}{$-N_{t}+V_{t}(i / 1+i)$} \\
\hline & & $\mathrm{i}=3 \%$ & $\mathrm{i}=6 \%$ & $\mathrm{i}=15 \%$ \\
\hline 1935 & $1,997.75$ & $(55.78)$ & $(0.89)$ & 146.61 \\
\hline 1936 & $1,657.15$ & $(56.27)$ & (10.73) & 111.62 \\
\hline 1937 & $2,045.39$ & (133.37) & (77.17) & 73.84 \\
\hline 1938 & 945.37 & (105.67) & (79.69) & $(9.89)$ \\
\hline 1939 & 911.49 & (81.09) & (56.04) & 11.26 \\
\hline 1940 & 689.32 & (61.47) & (42.53) & 8.36 \\
\hline 1941 & 402.57 & $(71.60)$ & $(60.54)$ & $(30.81)$ \\
\hline 1942 & 170.28 & $(56.68)$ & $(52.00)$ & $(39.43)$ \\
\hline 1943 & 52.46 & $(61.83)$ & $(60.38)$ & $(56.51)$ \\
\hline 1944 & 27.18 & $(43.02)$ & $(42.27)$ & $(40.26)$ \\
\hline 1945 & 29.18 & (25.66) & (24.86) & (22.71) \\
\hline 1946 & 101.56 & $(66.57)$ & $(63.78)$ & $(56.29)$ \\
\hline 1947 & 114.33 & $(92.27)$ & (89.13) & $(80.69)$ \\
\hline 1948 & $1,198.39$ & (271.46) & $(238.53)$ & (150.05) \\
\hline 1949 & 975.66 & $(383.80)$ & (356.99) & (284.96) \\
\hline 1950 & $2,319.55$ & (669.53) & $(605.79)$ & $(434.53)$ \\
\hline 1951 & $1,686.54$ & (805.86) & $(759.51)$ & $(635.00)$ \\
\hline 1952 & $3,766.17$ & (857.34) & $(753.86)$ & $(475.80)$ \\
\hline 1953 & 876.51 & (631.08) & $(607.00)$ & $(542.28)$ \\
\hline 1954 & $1,372.45$ & (917.93) & $(880.22)$ & (778.89) \\
\hline 1955 & $1,547.23$ & $(952.41)$ & (909.90) & (795.67) \\
\hline 1956 & $1,943.57$ & $(1,025.08)$ & (971.67) & (828.18) \\
\hline 1957 & $1,419.20$ & $(1,354.38)$ & $(1,315.38)$ & $(1,210.60)$ \\
\hline 1958 & 110.97 & $(1,225.67)$ & $(1,222.62)$ & $(1,214.43)$ \\
\hline 1959 & 33.28 & (986.72) & (985.80) & (983.34) \\
\hline 1960 & 228.80 & $(657.39)$ & $(651.10)$ & (634.21) \\
\hline 1961 & $2,608.93$ & $(1,266.56)$ & $(1,194.87)$ & $(1,002.25)$ \\
\hline 1962 & $2,930.71$ & $(1,463.29)$ & $(1,382.77)$ & $(1,166.39)$ \\
\hline 1963 & $2,646.11$ & $(1,430.65)$ & $(1,357.94)$ & $(1,162.57)$ \\
\hline 1964 & $2,607.30$ & $(1,398.58)$ & $(1,326.94)$ & $(1,134.44)$ \\
\hline 1965 & $2,071.58$ & $(1,294.64)$ & $(1,237.72)$ & $(1,084.77)$ \\
\hline 1966 & $2,566.76$ & $(1,137.62)$ & $(1,067.09)$ & (877.59) \\
\hline 1967 & $2,081.27$ & $(1,124.80)$ & $(1,067.61)$ & (913.95) \\
\hline 1968 & $1,516.93$ & (937.23) & $(895.55)$ & (783.56) \\
\hline 1969 & $1,574.04$ & $(1,076.00)$ & $(1,032.75)$ & (916.53) \\
\hline 1970 & $2,375.19$ & (980.85) & (915.58) & $(740.22)$ \\
\hline 1971 & $1,696.81$ & $(1,696.50)$ & $(1,649.88)$ & $(1,524.60)$ \\
\hline 1972 & $1,244.49$ & $(2,072.96)$ & $(2,038.77)$ & $(1,946.89)$ \\
\hline 1973 & $2,554.10$ & $(4,628.96)$ & $(4,558.78)$ & $(4,370.20)$ \\
\hline 1974 & $10,945.76$ & $(23,710.37)$ & $(23,409.60)$ & $(22,601.46)$ \\
\hline 1975 & $65,245.06$ & $(30,222.89)$ & $(28,430.12)$ & $(23,613.01)$ \\
\hline 1976 & $151,312.21$ & $(46,195.30)$ & $(42,037.61)$ & $(30,866.07)$ \\
\hline 1977 & $475,758.31$ & $(87,107.55)$ & $(74,034.88)$ & $(38,909.16)$ \\
\hline 1978 & $2,395,112.37$ & $(52,800.94)$ & $13,010.91$ & $189,844.47$ \\
\hline 1979 & $4,648,334.08$ & $(74,486.48)$ & $53,238.39$ & $396,429.56$ \\
\hline 1980 & $13,943,776.20$ & $(111,270.19)$ & $271,870.78$ & $1,301,353.75$ \\
\hline 1981 & $22,541,948.51$ & $(84,283.81)$ & $535,113.94$ & $2,199,408.50$ \\
\hline 1982 & $56,838,225.94$ & $(226,271.88)$ & $1,335,503.75$ & $5,531,927.00$ \\
\hline 1983 & $147,849,366.55$ & $(122,857.50)$ & $3,939,682.00$ & $14,855,550.00$ \\
\hline 1984 & $76,856,905.87$ & $(92,471.75)$ & $2,019,368.50$ & $7,693,791.50$ \\
\hline 1985 & $260,638,189.67$ & $(556,921.00)$ & $6,604,780.50$ & $25,847,960.00$ \\
\hline 1986 & $259,935,103.18$ & $(277,008.50)$ & $6,865,374.00$ & $26,056,646.00$ \\
\hline 1987 & $726,356,555.59$ & $(2,079,234.00)$ & $17,879,274.00$ & $71,506,912.00$ \\
\hline 1988 & $918,474,382.47$ & $(3,278,902.00)$ & $21,958,532.00$ & $89,770,424.00$ \\
\hline 1989 & $822,735,404.02$ & $(17,498,832.00)$ & $5,107,928.00$ & $65,851,312.00$ \\
\hline
\end{tabular}

$N_{t t}$ as in Table A.2

$\mathrm{Q}_{\mathrm{E}}$ is the stock targeted for exports 'assuming the ratio of the domestic utilisation of the resource to foreign utilisation remains constant'. Data derived from the data in Appendix A. 


\section{APPENDIX 2}

The adjustment proposed by Sefton and Weale to conventional income for the use of nonrenewable resources can be expressed as follows once the rate of interest is held constant over time: ${ }^{1}$

$$
N N P_{w}=N N P_{c}-s(0)\left(R_{1}(0)+R_{2}(0)\right)+\int_{0}^{\infty} s r R_{2} \exp \left(-\int_{0}^{t} r d \tau\right) d t \quad \text { [app-1] }
$$

$N N P_{w}$ and $N N P_{c}$ denote the welfare income and the conventional expenditure estimate of national income respectively. The rest of their nomenclature is as follows: $s$ represents the per unit price of the resource net of costs; $R_{1}$ the amount of the resource used domestically, $R_{2}$ the amount of the resource exported and $r$ is the rate of interest. As derived from the work of Weitzman [65], in the absence of natural resource, the conventional income equals the welfare income.

According to Sefton and Weale 'the term $-s(0)\left(R_{1}(0)+R_{2}(0)\right)$ is Hartwick's adjustment for the extraction of exhaustible resources in a closed economy'. Indeed, translating into our own notation we can write this term as $u\left(q_{1}+q_{2}\right)=N_{t}$, that is the per unit rent times the amount produced in the year. The remainder of the expression adds up to an imputed income on the stock of the resource targeted for export. Both terms together constitute the adjustment term proposed by Sefton and Weale.

They argue that a resource exporter 'can enjoy a level of positive consumption, because even though the country deplete its resource stock, the value of the remaining stock increases in value'. This, they say, can be illustrated clearly from the expression above. If the resource producing country exports all its oil, $R_{1}=0$, then they claim the adjustment term becomes

$$
-s R_{2}+\int_{0}^{\infty} r s R_{2} \exp \left(-\int_{0}^{t} r d \tau\right) d t=0
$$

So they conclude that 'in this case welfare income equals the conventional measure of NNP so there is effectively no adjustment required'. But how can the adjustment term be equal to zero? Take the alternative form of expressing the adjustment term also provided by Sefton and Weale. Define $S_{E}(t)$ as the amount of the present stock of the resource earmarked for export, so that

$$
S_{E}(t)=\int_{t}^{\infty} R_{2}(\tau) d \tau
$$

\footnotetext{
${ }^{1}$ This equation is a simplification of equation (46) in Sefton and Weale p.40, which originally reads: $\int_{0}^{\infty} r C_{1} \exp \left(-\int_{0}^{t} r d \tau\right) d t=C_{1}(0)+q_{1}(0) I_{1}(0)+\left(s(0) R_{2}(0)-T(0)\right)+r(0) H_{1}(0)-s(0)\left(R_{1}(0)+R_{2}(0)\right)+\int_{0}^{\infty} s r R_{2} \exp \left(-\int_{0}^{t} r d \tau\right) d t+\int_{0}^{\infty} r H_{1} \exp \left(-\int_{0}^{\infty} r d \tau\right) d t$

The left-hand side is welfare income. The four first terms in the right-hand side are the principal elements of the standard NNP: consumption, investment, the balance of trade and net property income. The last term corresponds to the imputed income due to future interest rate changes and it is equal to zero if the interest rate is not expected to change over time.
} 
Making use of Hotelling's rule, which implies that the price of the resource net of extraction costs increases over time at the rate of interest (this is the continuous version of the discrete equation app4 above), thus

$$
s=s(0) \exp \left(\int_{0}^{\tau} r d \tau\right)
$$

then the adjustment term can be expressed as:

$$
-s R_{2}+r(0) s(0) S_{E}
$$

This is simply the result of taking the solution of the integral side of the adjustment term from equation (48) in Sefton and Weale (assuming real interest remains constant). Since $R_{1}=0$, all of the resource is exported and $S_{E}$ equals the whole stock of the resource available $S(0)$. Observe that for adjustment term to become zero (so that no adjustment is required), the only possibility is that the ratio of production to reserves must equal the exogenous rate of interest $\left(R_{2} / S(0)=r\right)$, otherwise 'the adjustment could be positive or negative at any point along the optimal path'.

A closer look at the adjustment proposed by Sefton and Weale reveals that, if the whole of the resource is exported, their adjustment is conceptually equivalent to the adjustment framed by the Fundamental Equation of Asset Equilibrium. Translated into our notation, $s$ is the per unit price of the resource $u_{t} ; R_{2}$ is the quantity extracted for exports $q_{2}$ (understanding that total production equals production for domestic use plus production for exports, $q_{t}=q_{1}+q_{2}$ ); $Q$ was the notation used for the reserves or total stock $S(0)$; using discrete instead of continuous time formulation, so that the interest rate is $i$. If all the production is exported the adjustment proposed by Sefton and Weale becomes:

$$
-u_{t} q_{t}+\frac{i}{(1+i)} u_{t} Q_{t}
$$

the first term is simply $N_{t}$, and we know that $u_{t} Q$ is the value of the resource $V_{t}$ according to the Hotelling Valuation Principle (HVP), substituting

$$
-N_{t}+\frac{i}{(1+i)} V_{t}
$$

The adjustment proposed by Sefton and Weale is precisely the change in value of the asset, if the country exports all of its production, the per unit rents increase following Hotelling's rule and the interest rate does not change over time. In a closed economy model, where the country exports none of its resources and the rate of interest is constant, the adjustment is identical to the net price, $-N_{t}$, because there will be no gains from trade, thus $V_{t}$ is nil. For a lengthier description and the calculation of the values presented above see Chapters 2 and 5 in Rubio [52]. 


\title{
DATA APPENDICES BY COUNTRY
}

\author{
APPENDIX A: \\ Production and consumption of oil
}

Venezuela: 1920-1990:Baptista [9], cuadro B-5.

México: 1901-1992: México [35] cuadro 11.1, p.559.

Venezuela

APPENDIX B:

Exports

Total exports and oil exports:

- 1911-1963: Venezuela [60], p.1049. From 1911 to 1917 , 'oil exports' refer to asphalt exports.

- 1956-1967: Venezuela [61]. p.372, (overlapping years coincide with the previous source).

- 1965-1975: PODE for the years 1970, 1973 and 1975, p. 11 in all cases; (overlapping years coincide). From 1967 to 1975 there are some disagreements in the official published data over the value of oil exports due to different valuation (reference prices, tax prices, market prices)

- 1976-1985: PODE, 1985, pp.1 and 13.

Mexico

Total exports

- 1901-1990 (in dollars in the original): México [35], p. 799-800.

Oil exports

- 1911-1936: México [30] p.21 (converted here from volume to value by multiplying the former by the prices shown in Appendix F).

- 1937: Haber et al. [18].

- 1938-1939: Pemex [47], p.47.

- 1940-1974: Banco Nacional de Comercio Exterior [7]; (there were no exports between 1967 and 1973).

- 1974-1988: Pemex [50], p.121. 
APPENDIX D

Venezuela

Macroeconomic indicators

Total GDP:

- 1920-1989: base series at constant prices of 1968 from Baptista [8], pp.35-36 reflated by the corresponding deflator for GDP from the same source, pp.300-301.

NDP:

- 1920-1989: Calculated subtracting from the GDP the consumption of fixed capital at current prices found in Baptista [8], cuadro IV, p.48.

Mexico

Total GDP:

- $\quad$ 1901-1970 \& 1990: México [35], p.401-402, cuadro 8.1.

- 1987-1988, México [39], p.569, cuadro, 4.11.

- 1971-1987: México [32], p.318.

NDP/NNP (national income figures):

- 1929-1940: (National income) Sáenz [53] p.32.

- 1939-1960: (Net National income) Banco de México [5], p.73 (only used until 1950).

- 1939-1968: (Net national income used only from 1950 to 1960), Nacional Financiera[40], table 2.3 ), ultimate source is Banco de México.

- 1950-1978: NDP equals the GDP from the sources above minus the consumption of fixed capital calculated from Hofman series (see next heading below).

- 1979-1981: (NNP) México [38], p.26.

- 1980-1988: (NNP) Nacional Financiera[41] 1990, p146-147.

- 1989-1992: (NNP) México [36], p.33.

In order to obtain a complete data series for NDP, its series for the period 1979-1992 were calculated by subtracting the consumption of fixed capital from the GDP. The results are compatible with the NNP official series just referenced.

Consumption of fixed capital:

- The years pre-1960 calculated as the difference between the GDP and the national income, (see above).

- 1960-1978: the difference between the gross stock and the net stock of capital estimated by Hofman [25], Table E.20 reflated to current prices by the corresponding average price indices for buildings/infrastructure and machinery and equipment by México [35], pp.966967.

- 1977-1980: México [38], p.309.

- 1980-1988: Nacional Financiera[41], p146-147

- 1984-1987: México [34], p.559.

- 1988-1989: México [33], p.569.

- 1990-1992: México [36], p.33. 
Venezuela

\section{APPENDIX E:}

Oil reserves

\section{Oil Reserves}

- $1919,1924,1929,1934$ and 1939: [29], p.166.

- 1925 and 1935: United Nations [58], p.59.

- 1944-1970: Banco Central de Venezuela [3], p114.

- 1968-1976: Banco Central de Venezuela [4], p. 65 (data back to 1944; overlapping years coincide with the previous source).

- 1944-1985, PODE 1985, published the whole series.

At least until 1967, Venezuelan reserves included condensed materials. In 1982, the reserves of the Orinoco river in Amazonia were also included in the proven reserves despite the technical difficulties involved in their potential exploitation. From 1970 onwards, there are some important discrepancies between the figures published by the national offices and independent sources. These discrepancies obliged OPEC to publish two different sets of data for member countries,1970-1979 data available in the [44], p. 148.

Mexico

Oil reserves

- 1918: Pemex [49]

- 1938-1992: México [35] p.536.

For Mexico, reservoirs seems to include gas along with oil and therefore, the production of natural gas -converted into oil equivalents- were included included at the time of calculating the reserves/production ( $\mathrm{R} / \mathrm{P})$ ratio. Yet the average of $\mathrm{BP}$ [11] separate estimates for oil and gas (over 40 years for oil and above 70 years for gas in 1985) coincides with the figures presented here. The fact that our calculation is consistent with the R/P described by Sordo [56], pp. 102-103 for the history of Pemex provides some reassurance about its reliability.

\section{APPENDIX F:}

Oil prices

Venezuela

Oil prices: 1 921-1991: (in dollars per barrel in the original) Baptista [8]

Exchange rate (bolivar/US dollar):

- $\quad$ up to 1938: Venezuela [59], pp.417-420.

- 1939-1963: Venezuela [60], p.1046.

- 1963-1985: PODE, 1985, p.151

Mexico

Oil prices series knowing volumes and values produced and/or exported, oil prices were inferred from the following sources:

- 1901-1923: México [31],p. 28.

- 1923-1935: México [30], p.21.

- 1938-1939: Pemex [48], p.17.

- 1940-1973: Banco Nacional de Comercio Exterior [7] and Banco Nacional de Comercio Exterior [6]

- Prices 1975-1985: BP [10] p.14. Official Government selling prices on the first of January and July each year (average taken) for the Isthmus crude. 
Venezuela

APPENDIX G

Costs in the oil industry

Labour force:

- 1921-1990 Baptista [9], cuadro B-5.

Wages in oil industry:

- 1921-1990 Baptista [8], pp.139-141.

Mexico

Labour cost sources are as follow:

- 1934-1936: México [37], pp.477-510.

- 1937 Pemex [47].

- 1938-1992 México [35], p.573.

\section{APPENDIX H}

Venezuela

Capital Investment in the oil industry

Capital Investment in the Oil industry

- 1920-1946: Baptista [8], cuadro V-30, allocating 60 percent of total investment to the production branch of the industry.

- 1947-1961: Net capital investment in fixed assets in the production branch of the oil industry, Venezuela [62], p.24

- 1960-1970: Net capital investment in fixed assets in the production branch of the industry calculated from data in total net capital investment in fixed assets multiplied by the corresponding percentage of the production branch of the industry, PODE, 1970, p.142.

- 1964-1974: same procedure over data in PODE, 1974, p.13ff.

- 1975-1985: same procedure over data in PODE, 1985, p. 131

Overlapping data coincident, otherwise the most recent source was used.

Mexico

Capital Investment in the Oil Industry

- 1924: Dept. Estadística Nacional, as quoted in Gordon [16], p.53.

- 1935: México [37], cuadros 145-160.

- 1938-1979: México [35], p. 574.

- 1960-1985: Pemex [50] 
1. G. B. Asheim, Hartwick's rule in open economics, Canadian Journal of Economics (1986), 86, 395-402.

2. G. B. Asheim, Capital gains and net national product in open economies, Journal of Public Economics (1996), 59, 419-434.

3. Banco Central de Venezuela, La economía venezolana en los últimos treinta años, Caracas (1971).

4. Banco Central de Venezuela, La economía venezolana en los últimos treinta cinco años, Caracas (1978).

5. Banco de México, Informe anual, México D.F. (1960).

6. Banco Nacional de Comercio Exterior S.A., 6 años en el comercio exterior de México, México D.F. (1964).

7. Banco Nacional de Comercio Exterior S.A., Comercio Exterior de México, Editorial Cultura, México D.F. (Volumes for the period 1948-1973).

8. A. Baptista, Bases Cuantitativas de la Economía Venezolana, 1830-1989, Caracas (1991).

9. A. Baptista, Bases cuantitativas de la economía Venezolana. 1830-1995 (and data disk), Fundacion Polar, Caracas (1997).

10. British Petroleum, BP Statistical Review of World Energy, 1987, British Petrolum Company (1988).

11. British Petroleum, BP Statistical Review of World Energy, British Petrolum Company (yearly).

12. F. Coronil, The magical state: Nature, money, and modernity in Venezuela, University of Chicago Press, Chicago and London (1997).

13. P. Dasgupta and G. Heal, Economic Theory and Exhaustible Resources, Cambridge University Press, Cambridge (1979).

14. W. Easterly and M. Sewadeh, Global Development Network Growth Database, World Bank (2002).

15. L. W. Goodman, J. Mendelson Forman, M. Naim, J. S. Tulchin and G. Bland Eds., The lessons of the Venezuelan experience, Washington D.C. (1995).

16. W. C. Gordon, The Expropriation of Foreign-Owned Property in Mexico, Amercian Council of Public Affairs, Washington D.C (1941).

17. P. Gutman, The Measurement of Terms of Trade Effects, Review of Income and Wealth (1981), 27, 433-453.

18. S. H. Haber, N. Mauer and A. Razo, When Institutions do not Matter: The Rise and Decline of the Mexican Oil Industry, Paper presented at the Economic History Seminar at UC Berkeley, September 2001 (no published).

19. K. Hamada and K. Iwata, National Income, Terms of Trade and Economic Welfare, The Economic Journal (1984), 94, 752-771.

20. J. M. Hartwick, Intergenerational Equity and the Investing of Rents from Exhaustible Resources, American Economic Review (1977), 67, 972-974.

21. J. M. Hartwick, Natural resources, national accounting and economic depreciation, Journal of Public Economics (1990), 291-304.

22. J. M. Hartwick, Sustainability and constant consumption paths in open economies with exhaustible resources, Review of International Economics (1996), 3, 275-283.

23. J. R. Hicks, Value and Capital: An inquiry into some Fundamental Principles of Economic Theory, Oxford University Press, Oxford, UK (1946). 
24. A. A. Hofman and N. Mulder, The Comparative Productivity Performance of Brazil and Mexico, 1950-1994, in "Latin America and the World Economy since 1800" (J. H. Coatsworth and A. Taylor, Eds.), Cambridge, MA (1998).

25. A. A. Hofman, The Economic Development of Latin America in the Twentieth Century, Cheltenham, UK (2000).

26. International Bank for Reconstruction and Development (IBRD), The Economic Development of Venezuela, Baltimore (1961).

27. D. Irwin, Terms of Trade and Economic Growth in Nineteenth Century Britain, Bulletin of Economic Research (1991), 43, 93-101.

28. A. O. Krueger and $\mathrm{H}$. Sonnenschein, The Terms of Trade, the Gains from Trade, and Price Divergence, International Economic Review, 8, 121-127.

29. A. R. Martínez, El papel de la explotación petrolera en el proceso de modernización de la sociedad venezolana y la perspectiva inmediata, in "Hacia la Venezuela Postpetrolera [conference sponsored by la Academia Nacional de las Ciencias Económicas in 1985]" (F. Mieres, Ed.), Academia Nacional de Economía, Caracas (1989).

30. México, Government of, Estadística Petrolera, Revista de Industria. Revista Mensual (1937 December), 1, 21.

31. México. Departamento de la Estadística Nacional, El progreso económico de México. Un estudio económico estadístico, Republica Mexicana, México D.F. (1924).

32. México. Instituto Nacional de Estadística Geografía e Informática (INEGI), Estadísticas históricas de México, México D.F. (1990).

33. México. Instituto Nacional de Estadística Geografía e Informática (INEGI), Anuario Estadístico de los Estados Unidos Mexicanos, México D.F. (1990).

34. México. Instituto Nacional de Estadística Geografía e Informática (INEGI), Anuario Estadístico de los Estados Unidos Mexicanos, 1988-89, México D.F. (1990).

35. México. Instituto Nacional de Estadística Geografía e Informática (INEGI), Estadísticas históricas de México, México D.F. (1994).

36. México. Instituto Nacional de Estadística Geografía e Informática (INEGI), Sistema de Cuentas Nacionales de México1989-1992. Resumen General Vol. I, México D.F. (1994).

37. México. Secretaría de Patrimonio Nacional, El Petróleo de México, Goverment., México D.F. (1963).

38. México. Secretaría de Programación y Presupuesto, Anuario Estadístico de los Estados Unidos Mexicanos, 1981, México D.F. (1981).

39. México. Secretaría de Programación y Presupuesto, Anuario Estadístico de los Estados Unidos Mexicanos, 1989, México D.F. (1989).

40. Nacional Financiera, Statistics on the Mexican Economy, México D.F. (1974).

41. Nacional Financiera, La Economía Mexicana en Cifras, México D.F. (1991).

42. E. Newmayer, Measuring Genuine Savings: Are Most Resource-extracting Countries Really Unsustainable?, in "The Sustainability of Long-term Growth. Socioeconomic and Ecological Perspectives" (M. Munasinghe, O. Sunkel and C. de Miguel, Eds.), Edward Elgar, Cheltenham, UK (2001).

43. J. L. Nicholson, The Effects of International Trade on the Measurement of National Income, Economic Journal (1960), 70, 608-612.

44. Organisation of Petroleum Exporting Countries (OPEC), Annual Report, 1979, Vienna (1980).

45. D. W. Pearce and G. Atkinson, Capital Theory and the Measurement of Sustainable Development: An Indicator of Weak Sustainability, Ecological Economics (1993), 8, 103-108. 
46. D. W. Pearce and G. Atkinson, Measuring Sustainable Development, in "Handbook of environmental economics" (D. W. Bromley, Ed.), Blackwell, Cambridge, MA (1995).

47. PEMEX, (Petróleos Mexicanos), Informes del Director General Senador Antonio J.Bermúdez 1947-1952, México D.F. (1952).

48. PEMEX, (Petróleos Mexicanos), Realizaciones en petróleos mexicanos durante el período 1947-1952, México D.F. (1952).

49. PEMEX, (Petróleos Mexicanos), Informe del Director General, 1953-1960, México D.F. (1953-1960).

50. PEMEX, (Petróleos Mexicanos), Anuario Estadístico 1988, México D.F. (1988).

51. R. Repetto, Wasting Assets: Natural Resources In the National Income Accounts, The World Resources Institute, Washington, D.C. (1989).

52. M. d. M. Rubio Varas, Towards Environmental Historical National Accounts for Oil Producers: Methodological Considerations and Estimates for Venezuela and Mexico over the 20th Century, PhD thesis, London School of Economics, London (2002).

53. J. Sáenz, El ingreso nacional neto de México, 1929-1945, Revista de Economía (1946 February).

54. J. A. Sefton and M. R. Weale, The net national product and exhaustible resources: The effects of foreign trade, Journal of Public Economics (1996), 61, 21-47.

55. R. Solow, On the intergenerational allocation of natural resources, Scandinavian Journal of Economics (1986), 123-137.

56. A. M. Sordo and C. R. López, Exploración, Reservas y Producción de Petróleo en México, 1970-1985, Colegio de México, México D.F. (1988).

57. J. Spraos, Inequalising Trade? A Study of Traditional North/South Specialisation in the Context of Terms of Trade Concepts, New York (1983).

58. United Nations. Economic Commission for Latin America, Economic Developments in Venezuela in the 1950s, Economic Bulletin for Latin America (1960), 1, 21-61.

59. Venezuela. Ministerio de Fomento, Anuario Estadístico de Venezuela, 1938, Caracas (1940).

60. Venezuela. Ministerio de Fomento, Anuario Estadístico de Venezuela, 1957-1963, Caracas (1964).

61. Venezuela. Ministerio de Fomento, Anuario Estadístico de Venezuela, 1967, Caracas (1968).

62. Venezuela. Ministry of Mines and Hydrocarbons, Venezuelan Petroleum Industry.Statistical Data, Caracas (1962).

63. J. R. Vincent, T. Panayotou and J. M. Hartwick, Resource depletion and sustainability in small open economies, Journal of Environmental Economics and Management (1997), 33, 274-286.

64. M. R. Weale, Environmental Statistics and the National Accounts, in "The Environment and Emerging Development Issues" (P. Dasgupta and K. G. Mäler, Eds.), Oxford (1997).

65. M. L. Weitzman, On the Welfare Significance of National Product in Dynamic Economy, Quarterly Journal of Economics (1976), 90, 156-162.

66. M. L. Weitzman, Sustainability and Technical Progress, Scandinavian Journal of Economics (1997), 99, 1-13.

67. World Bank, Expanding the Measure of Wealth. Indicators of Environmentally Sustainable Development Vol. 17, Washington, D.C. (1997). 